\title{
Yeni Yapılacak Betonarme Bir Binanın TBDY 2018'e göre Deprem Performansının Belirlenmesi
}

\author{
Tolunay İBİ̧̧ ${ }^{1}$, Hakan ULUTAŞ ${ }^{2 *}$ \\ ${ }^{1}$ Yüksek Insaat Mühendisi, 16290, Bursa \\ ${ }^{2}$ Mehmet Akif Ersoy Üniversitesi, Mühendislik Mimarlık Fakültesi, Inş̧aat Mühendisliği Bölümü, Burdur \\ (ORCID: 0000-0003-2687-258X) (ORCID: 0000-0003-1721-7268)
}

\begin{abstract}
$\ddot{O} z$
Bu çalışmada, tasarımı TBDY (2018)'e göre yapılan ve yapımı devam eden betonarme bir binanın incelenmek üzere proje verileri elde edilmiştir. Binanın doğrusal elastik olmayan değerlendirme yöntemlerinden tek modlu statik itme analizi ile performans düzeyi belirlenmiştir. Elde edilen performans analizinin sonucu TBDY 2018'de verilen hedef performans seviyesi ile kıyaslanmıştır. Bina daha yapım aşamasında olduğundan yeni yapılacak bir bina gibi değerlendirilip performans analizi bu kapsamda yapılmıştır. Kesitlerin moment eğrilik analizleri ile plastik mafsal özelliklerinin belirlenmesi için SAP 2000'in "Section Desinger" arayüzünde faydalanılmıştır. Yapılan statik itme analizi sonucu kolon ve betonarme perdelerde herhangi bir hasar meydana gelmemiş, kirişlerin ise bazıları belirgin hasar bölgesinde kalmıştır. Düşey taşıyıcı elemanlarda hasar oluşmadığı için bina performans seviyesi kiriş hasarlarına bakılarak karar verilmiştir. Binanın yönetmelikte verilen hedef performans seviyesini sağladığı belirlenmiştir.
\end{abstract}

Anahtar kelimeler: Tek modlu statik itme analizi, Yeni betonarme bina, TBDY 2018, Performans analizi, Deprem güvenliği.

\section{Determining the Seismic Performance of a New Reinforced Concrete Building According to Turkish Seismic Code 2018}

\begin{abstract}
In this study, the Project data were obtained in order to investigate a reinforced concrete building whose design was made according to Turkish Seismic Code (TSC-2018) and whose construction continues. The performance level of the building was determined by using static single-mode pushover analysis, one of the nonlinear evaluation methods. The result of the obtained performance analysis has been compared with the target performance level given in the Turkish Seismic Code. Since the building is still under construction, it is evaluated as a new building and performance analysis has been made within this scope. Plastic hinge properties was determined in SAP 2000's Section Designer interface by using moment curvature analysis of sections. As a result of the static single-mode pushover analysis), no damage occurred on the columns and reinforced concrete walls, and some of the beams remained in the obvious damage zone. Since there was no damage to the vertical bearing elements, the building performance level was decided by looking at the beam damages. It has been determined that the building achieved the target performance level given in Turkish Seismic Code.
\end{abstract}

Keywords: Static single-mode pushover analysis, New reinforced concrete building, TSC 2018, Performance analysis, Seismic safety.

\section{Giriş}

Ülkemiz, aktif bir deprem kuşağı olan Alp-Himalaya deprem kuşağında bulunduğundan ve jeolojik oluşumunu geç tamamlamış genç bir ana karaya sahip olmasından dolayı sıklıkla deprem hareketlerine maruz kalmaktadır[1]. Meydana gelen bu depremlerin sebep olduğu can ve maddi kayıplar depreme dayanıklı yapı tasarımını ve mevcut yapıların deprem performansı değerlendirmesini her geçen gün daha da önemli hale getirmiş̧ir. Performansa dayalı tasarım ve değerlendirme ilk olarak, Amerika Birleşik Devletleri'nde, 1996 yılında çıkan Betonarme Binaların Sismik Değerlendirilmesi ve Güçlendirilmesi

"Sorumlu yazar: hakannulutas@gmail.com

Geliş Tarihi: 12.04.2021, Kabul Tarihi: 09.06.2021 
(ATC 40) [2] ve 2000 yılında yayınlanan Binaların Sismik İyileştirilmesi için Önstandart ve Açıklamalar (FEMA 356) [3] gibi standartlarda geniş bir şekilde yer almıştır [4]. Ülkemizde ise mevcut binaların deprem performansının değerlendirilmesi kavramı il olarak 2007 yılında yayınlanan Deprem Bölgelerinde Yapılacak Binalar Hakkında Yönetmelik 2007 (DBYBHY 2007) [5]'nin 7. Bölümünde yer almıştır. DBYBHY (2007) [5] yalnız mevcut binaların deprem performansını kapsamaktaydı. Yeni yapılacak binaların deprem performansının belirlenmesi kavramı ise il kez 1 Ocak 2019 tarihi ile yürürlüğe giren Türkiye Bina Deprem Yönetmeliği(TBDY 2018) [6] içeresinde yer almıştır.

Mevcut binaların deprem performansının belirlenmesi üzerine literatürde birçok çalışma olup bunların büyük bir kısmı DBYBHY (2007) [5]'e göre yapılmıştır [4, 7-13]. TBDY (2018) [6]'in yürürlüğe girmesi ile birlikte bu yönetmelikte verilen esaslara göre de binaların performans değerlendirmesi üzerine çalışmalar yapılmaya başlanmıştır. Bunlardan, Kap vd. [14], 1999 Marmara ve Düzce depremlerinden etkilenmiş mevcut bir okul binasının TBDY (2018) [6]'e göre deprem performans analizini yaparak binadaki taşıyıcı elemanların kapasitelerini belirlemişlerdir. Kürkçü [15] tarafindan yapılan tez çalışmasında, 20 katı betonarme bir yapının TBDY (2018) [6]'e göre tasarımı ve deprem performansı zaman tanım alanında hesap yöntemi ile belirlenmiştir. Akçora [16] tarafından yapılan tez çalışmasında, 30 katlı betonarme yüksek bir bina Türkiye Bina Deprem yönetmeliğine göre incelenmiştir. Yapılan analizler sonucunda kesitler için elde edilen plastik şekil değiştirme ve dönme değerleri TBDY (2018) [6]'de verilen sınırları sağladığı belirlenmiştir. Çapa [17], 3, 5 ve 7 katlı 3 adet model bina oluşturmuş, bu binaların deprem performanslarını TBDY (2018) [6]'de verilen doğrusal ve doğrusal olmayan hesap yöntemleri ile belirlemiş, elde edilen sonuçları birbiriyle karşılaştırırmıştır.

$\mathrm{Bu}$ çalışmada, yeni yapılacak betonarme bir binanın deprem performansının doğrusal elastik olmayan değerlendirme yöntemlerinden tek modlu statik itme analizi ile belirlenmesi amaçlanmıştır. Binanın performansının belirlenebilmesi için kesitlerin moment eğrilik analizleri ile plastik mafsal özelliklerinin belirlenmesi gerekmektedir. Bunun için SAP 2000 [18]'in "Section Desinger" arayüzünden faydalanılmıştır. Yapılan analiz sonucu kolon, kiriş ve betonarme perdelerde meydana gelen hasarlardan faydalanarak bina performans düzeyi belirmiştir. Elde edilen performans analizinin sonucu TBDY (2018) [6]'de verilen hedef performans seviyesi ile kıyaslanmıştır.

\section{Materyal ve Metot}

Mevcut veya yeni yapılacak betonarme binaların performans seviyesinin belirlenmesi için TBDY (2018) [6]'de doğrusal elastik ve doğrusal elastik olmayan olmak üzere iki yöntem önerilmektedir. Doğrusal elastik hesap yönteminde dayanım esaslı çözüm yapılırken, doğrusal elastik olmayan hesap yönteminde şekil değiştirme ve yer değiştirme odaklı çözüm yapılmaktadır. Bu çalışmada incelenen binanın performansı doğrusal elastik olmayan hesap yöntemlerinden tek modlu itme yöntemi ile yapılmıştır.

\subsection{Kesit Hasar Durumları}

TBDY (2018) [6]'de sünek elemanlar için kesit düzeyinde Sınırlı Hasar (SH), Kontrollü Hasar (KH) ve Göçme Öncesi Hasar (GÖ) olmak üzere üç hasar durumu ve hasar sınırı tanımlanmıştır. Kesitteki sınırlı miktarda elastik ötesi davranış sınırlı hasarla, kesit dayanımının güvenli olarak sağlanabileceği elastik ötesi davranış kontrollü hasarla, ileri düzeyde elastik ötesi davranış ise göçme öncesi hasarla ifade edilmektedir. Gevrek olarak hasar gören elemanlar bu sinıflandırmaya dahil edilmez.

\subsection{Kesit Hasar Sinırları}

TBDY (2018) [6]'de yayılı ve yığılı plastik davranış modellerine bağlı olarak kesit hasar sınırları verilmiştir. Yayılı plastik davranış modelinde şekil değiştirmeye bağlı hasar sınırları, yığılı plastik davranış modelinde ise plastik dönme kapasitesine bağlı hasar sınırları verilmiştir. Bu çalışmada çubuk eleman olarak modellenen kolon, kiriş ve betonarme perdelerde, doğrusal olmayan davranış modeli olarak yığılı plastik davranış (plastik mafsal) modeli kullanılmıştır. Sınırlı hasar (SH), kontrollü hasar $(\mathrm{KH})$ ve göçme öncesi hasar (GÖ) durumları için yığılı plastik davranış modeline göre verilen hasar sinırları Tablo 1'de verilmiştir. 
Tablo 1. Hasar durumlarına göre dönme kapasitesi sınırları [6]

\begin{tabular}{|c|c|}
\hline Hasar sınırı & Plastik Dönme Sinırı $\left(\boldsymbol{\theta}_{\mathrm{p}}\right)$ \\
\hline $\mathrm{GÖ}$ & $\theta_{\mathrm{p}}^{(\mathrm{GÖ})}=\frac{2}{3}\left(\left(\phi_{\mathrm{u}}-\phi_{\mathrm{y}}\right) L_{\mathrm{p}}\left(1-0.5 \frac{L_{\mathrm{p}}}{L_{\mathrm{s}}}\right)+4.5 \phi_{\mathrm{u}} d_{\mathrm{b}}\right)$ \\
\hline $\mathrm{KH}$ & $\theta_{\mathrm{p}}^{(\mathrm{KH})}=0.75 \theta_{\mathrm{p}}^{(\mathrm{GÖ})}$ \\
\hline $\mathrm{SH}$ & $\theta_{\mathrm{p}}^{(\mathrm{SH})}=0$ \\
\hline
\end{tabular}

Tablo 1'de $\phi_{u}$ ile verilen kesitteki göçme öncesi toplam eğriliği; $\phi_{y}$, plastik mafsal kesitindeki etkin akma eğriliğini; $L_{\mathrm{s}}$, kesme açıklı̆ını; $L_{\mathrm{p}}$, plastik mafsal boyunu; $d_{\mathrm{b}}$, ise düğüm noktasındaki donatıların ortalama çapını ifade etmektedir. Bu çalışmada, kesme açıklığı $\left(L_{s}\right)$ kolon ve kirişlerde net açıklığın yarısı, betonarme perdelerde ise her katın tabanından perde tepesine olan uzaklığın yarısı olarak alınmıştır. Plastik mafsal boyu olarak adlandırılan plastik şekil değiştirme bölgesinin uzunluğu $\left(L_{\mathrm{p}}\right)$, çalışan doğrultudaki kesit boyutu (h)'nun yarısına eşit alınmıştır.

\subsection{Kesit Hasar Bölgeleri}

TBDY (2018) [6]'de Sınırlı Hasar Bölgesi, Belirgin Hasar Bölgesi, İleri Hasar Bölgesi ve Göçme bölgesi olmak üzere 4 hasar bölgesi tanımlanmıştır. Elemanın hangi hasar bölgesinde kaldığına elemanın kritik kesitindeki hasara bakarak karar verilir. Eğer elemanın hasarı, sınırlı hasara ulaşamamışsa sınırlı Hasar bölgesinde, sınırlı ile kontrollü hasar arasında ise belirgin hasar bölgesinde, kontrollü hasar ile göçme öncesi arasında ise ileri hasar bölgesinde, göçme öncesi hasar sınırını aşmışsa göçme bölgesindedir (Şekil 1).

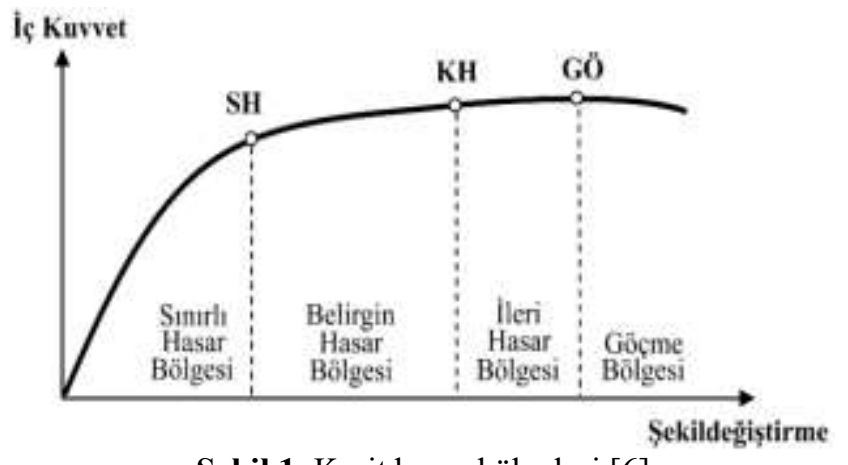

Şekil 1. Kesit hasar bölgeleri [6]

\subsection{Performans Düzeyleri}

TBDY (2018) [6]'de betonarme yapılar için Kesintisiz Kullanım(KK) performans düzeyi, Sınırlı Hasar(SH) performans düzeyi, Kontrollü Hasar(KH) performans düzeyi, Göçmenin Önlenmesi(GÖ) performans düzeyi olmak üzere 4 performans düzeyi verilmiştir. Bu dört performans düzeyinden herhangi birini sağlayamayan binalar Göçme Durumu'ndadır.

\subsubsection{Kesintisiz kullanım (KK) performans düzeyi}

Kesintisiz Kullanım(KK) performans düzeyi, bina taşıyıcı sistem elemanlarında yapısal hasarın oluşmadığı veya hasarın ihmal edilebilir ölçüde kaldığı duruma ifade etmektedir.

\subsubsection{Sınırlı hasar (SH) performans düzeyi}

Binanın taşıyıcı sistem elemanlarının sınırlı düzeyde hasar görmesi veya doğrusal olmayan davranışın sınırlı kalmasını ifade eden performans düzeyidir. TBDY (2018) [6]'e göre binanın performans seviyesinin sınırlı hasar olması için aşağıdaki koşulları sağlaması gerekmektedir.

- Binanın herhangi bir katında, her iki deprem doğrultusu için yapılmış olan performans analizi sonucu, kirişlerin en fazla \%20'si belirgin hasar bölgesi' ne geçebilir. 
- Düşey taşıyıcı elemanların tamamı sınırlı hasar bölgesi içerisinde bulunmak zorundadır.

- Gevrek hasar gören elemanlar var ise, bu elemanların güçlendirilmesi gerekmektedir.

\subsubsection{Kontrollü hasar (KH) performans düzeyi}

Binanın taşıyıcı sistem elemanlarının can güvenliğini sağlayacak şekilde çok ağır olmayan hasar görmesi veya meydana gelen hasarın onarılabilir olması durumunu ifade eder. TBDY 2018'e göre binanın performans seviyesinin kontrollü hasar olması için aşağıdaki koşulları sağlaması gerekmektedir.

- Binanın herhangi bir katında, her iki deprem doğrultusu için yapılmış olan performans analizi sonucu, kirişlerin için en fazla \%35'lik kısmı ileri hasar bölgesi' ne geçebilir. İkincil (yatay yük taşıyıcı sisteminde yer almayan) kirişler bu yüzdelik hesabında işleme dâhil edilmez.

- Ileri hasar bölgesi 'nde bulunun düşey taşıyıcı elemanların, her kat için düşey taşıyıcı elemanlar tarafindan karşılanan kesme kuvvetine toplam katkısı \%20' den daha az olmalıdır. En son kat için ise ileri hasar bölgesi'ne geçen düşey taşıyıcı elemanların kesme kuvveti, yine son katta bulunan düssey taşıyıcı elemanların toplam kesme kuvvetine oranı en fazla \%40 olmalıdır.

- Diğer kalan tüm taşıyıcı elemanlar sinırlı hasar bölgesi veya belirgin hasar bölgesi'ndedir. Ancak, binanın herhangi bir katında alt ve üst kesitlerinin her ikisi birden belirgin hasar bölgesi'ni aşan düşey taşıyıcı elemanların karşıladığı kesme kuvvetinin, aynı kattaki tüm düşey taşıyıcı elemanların karşıladığı kesme kuvvetine oranı \%30’un altında olması gerekir.

\subsubsection{Göçmenin önlenmesi (GÖ) performans düzeyi}

Binanın taşıyıcı sistem elemanlarının ileri düzey hasar gördüğü göçme öncesi durumu ifade etmektedir. TBDY (2018) [6]'e göre binanın performans seviyesinin göçmenin önlenmesi olması için aşağıdaki koşulları sağlaması gerekmektedir.

- Binanın herhangi bir katında, her iki deprem doğrultusu için yapılmış olan performans analizi sonucu, kirişlerin için en fazla \%20 lik kısmı göçme bölgesi' ne geçebilir. İkincil (yatay yük taşıyıcı sisteminde yer almayan) kirişler bu yüzdelik hesabında işleme dâhil edilmez.

- Diğer tüm taşıyıcı elemanlar sinırl hasar bölgesi, belirgin hasar bölgesi veya ileri hasar bölgesi'ndedir. Ancak, Binanın herhangi bir katında alt ve üst kesitlerinin her ikisi birden belirgin hasar bölgesi'ni aşan düşey taşıyıcı elemanların karşıladığı kesme kuvvetinin, aynı kattaki tüm düşey taşıyıcı elemanların karşıladığı kesme kuvvetine oranı \%30'un altında olması gerekir.

- Göçme öncesi performans düzeyindeki bir binanın kullanılması can güvenliği açısından sakıncalıdır.

\subsubsection{Göçme durumu}

Göçmenin önlenmesi performans düzeyi'ni sağlayamayan binalar göçme durumu'ndadır. Göçme durumundaki bir binanın kullanılması can güvenliği açısından sakıncalıdır.

\subsection{Bina Performans Hedefleri}

TBDY 2018'de yeni yapılacak binaların sağlamları gereken performans hedefleri deprem tasarım sınıflarına göre Tablo 2'de verilmiştir. Ayrıca bu tabloda binanın performans hedefinin belirlenmesinde uygulanacak değerlendirme/tasarım yaklaşımları da belirtilmiştir.

Tablo 2. Deprem tasarım sınıflarına göre yeni yapılacak binalar için performans hedefleri ve uygulanacak değerlendirme/tasarım yaklaşımları [6]

\begin{tabular}{|c|c|c|c|c|}
\hline \multirow{2}{*}{$\begin{array}{c}\text { Deprem Yer } \\
\text { Hareket Düzeyi }\end{array}$} & \multicolumn{2}{|c|}{ DTS $=1,1 \mathrm{a}^{(1)}, 2,2 \mathrm{a}^{(1)}, 3,3 \mathrm{a}, 4,4 \mathrm{a}$} & \multicolumn{2}{c|}{ DTS $=1 \mathrm{a}^{(2)}, 2 \mathrm{a}^{(2)}$} \\
\cline { 2 - 5 } & $\begin{array}{c}\text { Normal Performans } \\
\text { Hedefi }\end{array}$ & $\begin{array}{c}\text { Değerlendirme/Tasarım } \\
\text { Yaklaşımı }\end{array}$ & $\begin{array}{c}\text { İleri Performans } \\
\text { Hedefi }\end{array}$ & $\begin{array}{c}\text { Değerlendirme/Tasarım } \\
\text { Yaklaşımı }\end{array}$ \\
\hline DD-3 & - & - & SH & ŞGDT \\
\hline DD-2 & - & DGT $^{(5)}$ & KH & DGT $^{(3,4)}$ \\
\hline DD-1 & - & - & KH & ŞGDT \\
\hline
\end{tabular}

${ }^{(1)}$ BYS > 3 olan binalarda, ${ }^{(2)} \mathrm{BYS}=2,3$ olan binalarda uygulanacaktır. 


\section{Bulgular ve Tartışma}

$\mathrm{Bu}$ çalışmada, yeni yapılacak 8 katlı betonarme bir binanın deprem performansı incelenmiştir. Bu kapsamda Bursa ili Yıldırım ilçesinde bulunan ve TBDY (2018) [6]'e göre tasarlanıp yapımına devam edilen bir binanın incelenmek üzere proje verileri elde edilmiştir. Binanın genel özellikleri aşağıda maddeler halinde sıralanmıştır.

- Kat sayısi: 8

- Kat yüksekliği (h): $2.8 \mathrm{~m}$

- Yapı toplam yüksekliği: $22.4 \mathrm{~m}$

- Yap1 taban alanı: $312 \mathrm{~m}^{2}$

- Yap1 Kullanım Amaci: Konut

- Beton sinifi: C35

- Donatisi sinifi: S420

- Yerel zemin sinifi: ZD

$\mathrm{X}$ eksenine göre simetrik olan binanın kalıp planı Şekil 2'de verilmiştir. 


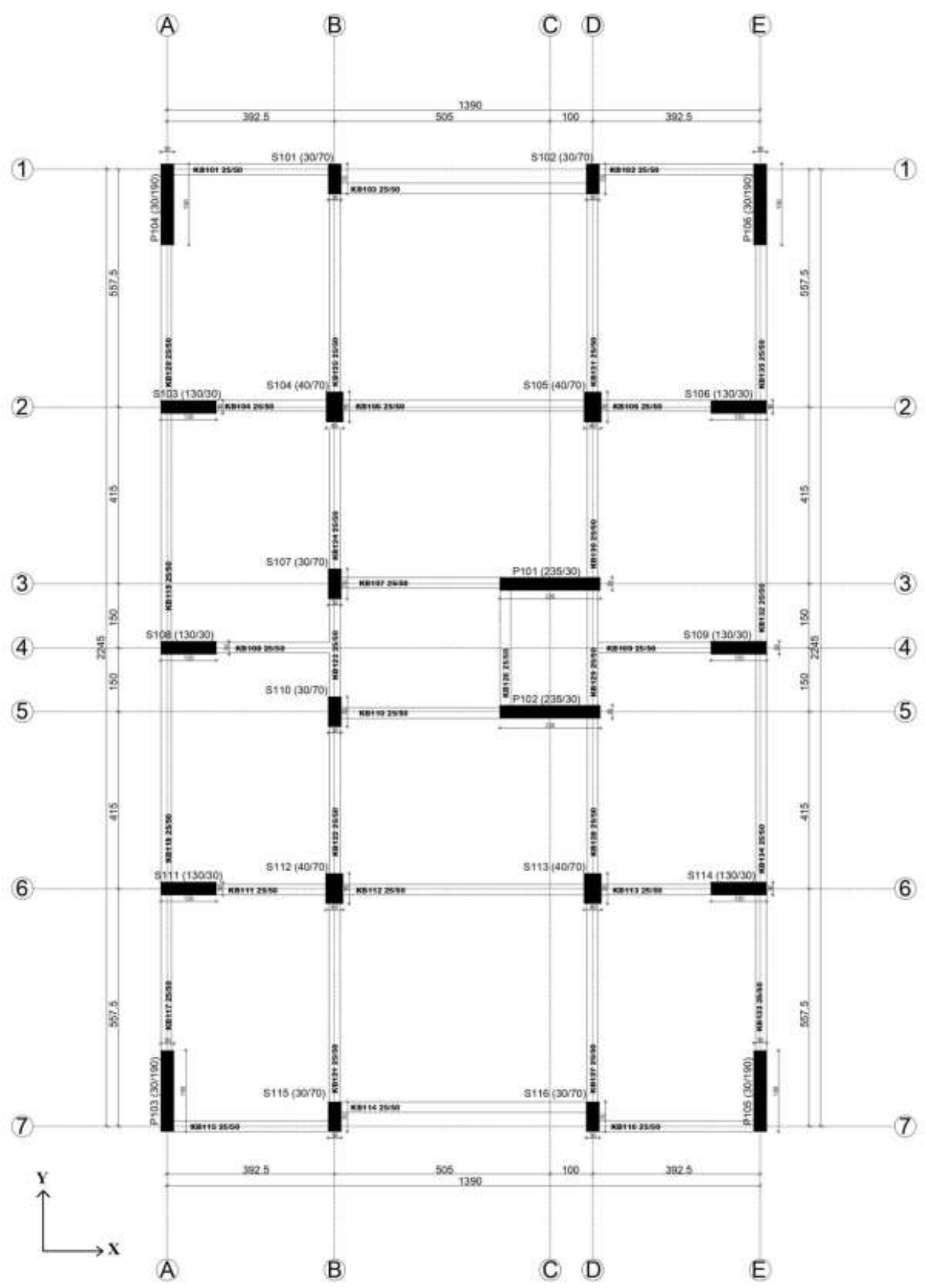

Şekil 2. Tüm katların kalıp planı 


\subsection{Analiz Modelinin Oluşturulması}

İncelenen binanın 3D modeli, SAP 2000 v21. [18] programı ile oluşturulmuştur (Şekil 3).

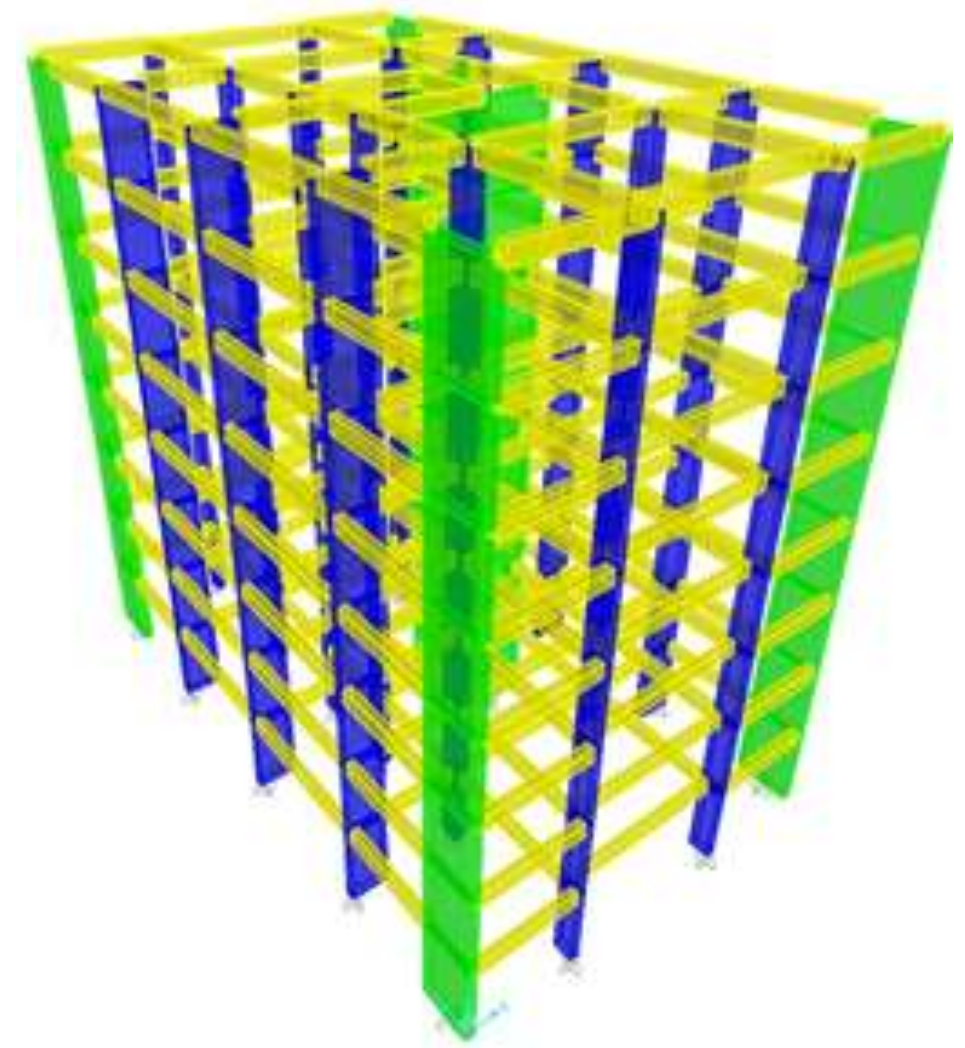

Şekil 3. Binanın SAP 2000'de oluşturulan modeli

\subsection{Kesitlerin Plastik Mafsal Özeliklerinin Oluşturulması}

Taşıyıcı sistem elemanlarında meydana gelecek hasarların tespit edilebilmesi için bu elemanların plastik mafsal özelliklerinin belirlenmesi gereklidir. Kesitlerin plastik mafsal özeliklerinin belirlenebilmesi için ise her bir kesitin moment eğrilik analizlerinin yapılması gerekmektedir. Bu çalışmada kesitlerin moment eğrilik analizleri SAP 2000 programında "Section Designer" arayüzünde yapılmıştır.

\subsubsection{Doğrusal olmayan malzemenin modellenmesi}

TBDY 2018' in 5.4.1.5 (b) maddesine göre yeni yapılacak olan yapılarda Şekil Değiştirmeye Göre Değerlendirme ve Tasarım yaklaşımında beton ve donatının beklenen ortalama dayanımları kullanılmalıdır. Beton ve donatının beklenen ortalama dayanımları Tablo 3 'te verilmiştir.

Tablo 3. Malzemelerin beklenen ortalama dayanımları [6]

\begin{tabular}{|l|l|}
\hline Beton & $f_{c e}=1.3 f_{c k}$ \\
\hline Donatı Çeliği & $f_{y e}=1.2 f_{y k}$ \\
\hline
\end{tabular}

Burada, $\boldsymbol{f}_{\boldsymbol{c} \boldsymbol{e}}$; betonun ortalama basınç dayanımını, $\boldsymbol{f}_{\boldsymbol{c} \boldsymbol{k}} ;$ beton karakteristik basınç dayanımı, $\boldsymbol{f}_{\boldsymbol{y} \boldsymbol{k}}$; donatı çeliği karakteristik akma dayanımını, $\boldsymbol{f}_{\boldsymbol{y} \boldsymbol{e}}$; donatı çeliğinin ortalama basınç dayanımını ifade etmektedir.

Moment eğrilik analizlerinde kullanılan beton ile donatının özellikleri Tablo 4'te verilmiştir. Donatı çeliğinin bu özeliklerinin belirlenmesinde TBDY 2018 [6] Tablo 5A.1.'den faydalanılmıştır. 
Tablo 4. Beton ve donatının özellikleri

\begin{tabular}{|l|l|}
\hline \multirow{4}{*}{ Beton } & $f_{c k}: 35 \mathrm{~N} / \mathrm{mm}^{2}$ \\
\cline { 2 - 3 } & $f_{c e}=1.3 \times 35=45.5 \mathrm{~N} / \mathrm{mm}^{2}$ \\
\cline { 2 - 3 } & $E_{c}: 3250 \sqrt{45.5}+14000=35922.45 \mathrm{~N} / \mathrm{mm}^{2}$ \\
\hline \multirow{5}{*}{ Donat1 } & $f_{\text {ye }}=1.2 \times 420=504 \mathrm{~N} / \mathrm{mm}^{2}$ \\
\cline { 2 - 3 } & $E_{s}: 200000 \mathrm{~N} / \mathrm{mm}^{2}$ \\
\cline { 2 - 3 } & $\varepsilon_{\mathrm{sy}}: 0.0021$ \\
\cline { 2 - 3 } & $\varepsilon_{\mathrm{s}}: 0.008$ \\
\cline { 2 - 3 } & $\varepsilon_{\mathrm{s}}: 0.08$ \\
\cline { 2 - 3 } & $\mathrm{f}_{\mathrm{sy}}: 504 \mathrm{~N} / \mathrm{mm}^{2}$ \\
\cline { 2 - 3 } & $\mathrm{f}_{\mathrm{su}}: 1.15^{*} 504=580 \mathrm{~N} / \mathrm{mm}^{2}$ \\
\hline
\end{tabular}

Burada, $E_{c}$; betonun elastiste modülünü, $E_{s}$; donatı çeliğinin elastiste modülünü, $\varepsilon_{\mathrm{sy}}$, donatı çeliğinin akma birim şekildeğiştirmesini, $\varepsilon_{\text {sh }}$; donatı çeliğinin pekleşme başlangıcındaki birim şekildeğiştirmesini, $f_{\text {sy }}$; donatı çeliğinin akma dayanımını, $f_{\text {su; }}$ donatı çeliğinin kopma dayanımını ifade etmektedir.

Tablo 4'te verilen özeliklere bağlı olarak sargısız beton ile donatı için oluşturulan gerilme şekildeğiştirme diyagramı Şekli 4'te verilmiştir.

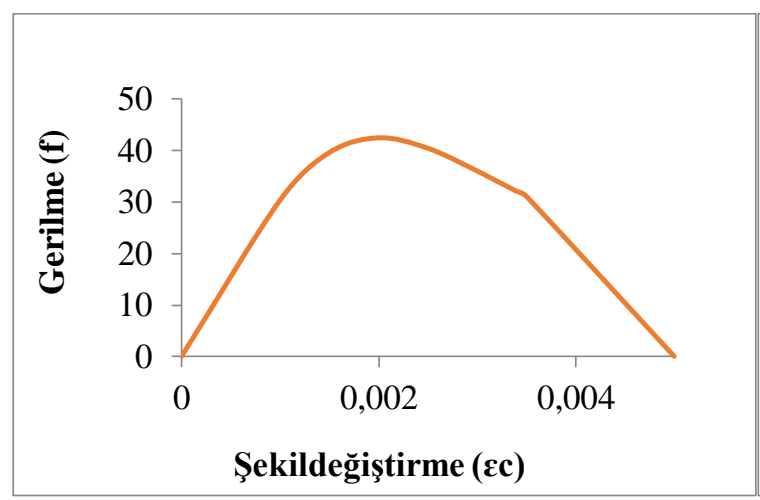

(a)

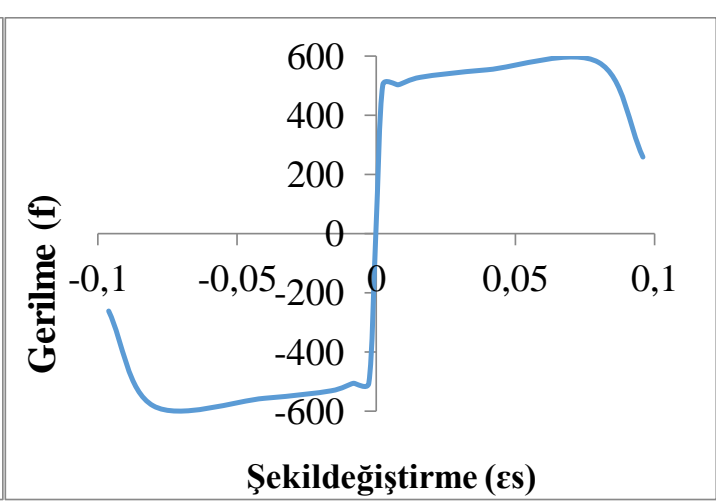

(b)

Şekil 4. Sargısız beton(a) ile donatının (b) gerilme-şekil değiştirme diyagramı

\subsubsection{Kiriş kesitlerinin plastik mafsal özelliklerinin belirlenmesi}

Kesitlerin plastik mafsal özellikleri, enine ve boyuna donatı, kesit boyutları ve açıklık mesafesine bağl1 olarak değişmektedir. Bu özellikleri aynı olan kirişlere bir tip kesit ismi verilmiştir. İncelenen binada 9 farklı tip kesit vardır. Her tip kiriş için B1'den B9'a kadar isim verilmiştir. Kiriş tip kesitlerinin özelikleri Tablo 5'te verilmiştir. Kiriş özelikleri katlara göre değişiklik göstermediğinden tabloda sadece 1. katın kirişleri yazılmışıır.

Tablo 5. Kiriş tip kesitleri ve bilgileri

\begin{tabular}{|c|c|c|c|c|c|c|}
\hline \multirow[b]{2}{*}{$\begin{array}{l}\text { Kesit } \\
\text { Tipi }\end{array}$} & \multirow[b]{2}{*}{ Kiriş Adı } & \multirow[b]{2}{*}{$\begin{array}{l}\mathrm{b} \times \mathrm{h} \\
(\mathrm{cm})\end{array}$} & \multirow{2}{*}{$\begin{array}{l}\text { Net } \\
\text { Açılık } \\
(\mathrm{m})\end{array}$} & \multicolumn{3}{|c|}{ Donatı Bilgileri } \\
\hline & & & & Alt Donatı & Üst Donat1 & \begin{tabular}{|l} 
Enine \\
Donat1
\end{tabular} \\
\hline B1 & K101-K102-K115-K116 & \multirow{9}{*}{$25 \times 50$} & 3.60 & $2 \varnothing 12+2 \varnothing 14$ & $2 \varnothing 12+2 \varnothing 14$ & \multirow{9}{*}{$8 \varnothing / 9$} \\
\hline B2 & K103-K105-K112-K114 & & 5.75 & $2 \varnothing 14+2 \varnothing 16$ & $5 \varnothing 14$ & \\
\hline B3 & K104-K106-K108-K109-K111-K113 & & 2.60 & $2 \varnothing 12+2 \varnothing 16$ & $2 \varnothing 12+3 \varnothing 16$ & \\
\hline B4 & K107-K110 & & 3.70 & \begin{tabular}{|l|l|}
$4 \varnothing 12$ \\
\end{tabular} & $2 \varnothing 12+3 \varnothing 14$ & \\
\hline B5 & $\begin{array}{l}\text { K117-K120-K133-K135-K122-K124- } \\
\text { K128-K130 }\end{array}$ & & 3.65 & $2 \varnothing 12+2 \varnothing 16$ & $2 \varnothing 14+2 \varnothing 16$ & \\
\hline B6 & K121-K125-K127-K131 & & 4.65 & $4 \varnothing 16$ & $2 \varnothing 14+3 \varnothing 16$ & \\
\hline B7 & K118-K119-K132-K134 & & 5.35 & $1 \varnothing 14+2 \varnothing 16$ & $3 \varnothing 14$ & \\
\hline B8 & K126-K129 & & 2.70 & $1 \varnothing 14+2 \varnothing 16$ & $3 \varnothing 12$ & \\
\hline B9 & K123 & & 2.30 & $2 \varnothing 14+2 \varnothing 16$ & 5012 & \\
\hline
\end{tabular}


Yapılan moment eğrilik analizi sonucu 9 tip kesitin her birinin akma eğrilikleri $\left(\phi_{y}\right)$, göçme öncesi eğrilikleri $\left(\phi_{u}\right)$, akma momentleri $\left(\mathrm{M}_{\mathrm{y}}\right)$ ve göçme öncesi momentleri $\left(\mathrm{M}_{\mathrm{u}}\right)$ elde edilmiştir. Kirişler için bulunan bu değerlerde akma yüzeyi olarak $0^{0}$ ve $180^{\circ}$ için hesaplama yapılmıştır. B2 tip kirişinin moment eğrilik analizi sonucu elde edilen değerleri Tablo 6'da verilmiştir.

Tablo 6. B2 tip kirişin eğrilik analizi değerleri

\begin{tabular}{|c|c|c|c|c|c|}
\hline \multirow{2}{*}{ Kiriş Tipi } & Akma Yüzeyi & $\phi_{\mathrm{y}}\left(\mathrm{m}^{-1}\right)$ & $\mathrm{M}_{\mathrm{y}}(\mathrm{kNm})$ & $\phi_{\mathrm{u}}\left(\mathrm{m}^{-1}\right)$ & $\mathrm{M}_{\mathrm{u}}(\mathrm{kNm})$ \\
\hline \multirow{2}{*}{$\mathrm{B} 2$} & $0^{0}$ & 0.00807 & 173.4675 & 0.1865 & 180.0126 \\
\cline { 2 - 6 } & $180^{0}$ & 0.00823 & 187.4965 & 0.1868 & 194.8395 \\
\hline
\end{tabular}

Tablo 6'da yer alan değerler dikkate alınarak sınırlı hasar, kontrollü hasar ve göçme öncesi hasar durumlarının her biri için plastik dönme sınır değerleri hesaplanmıştır. $0^{0}$ akma yüzeyi için hesaplanan plastik dönme sınır değerleri aşağıda verilmiştir.

$\theta_{\mathrm{p}}^{(\mathrm{GÖ})}=\frac{2}{3}\left(\left(\phi_{\mathrm{u}}-\phi_{\mathrm{y}}\right) L_{\mathrm{p}}\left(1-0.5 \frac{L_{\mathrm{p}}}{L_{\mathrm{s}}}\right)+4.5 \phi_{\mathrm{u}} d_{\mathrm{b}}\right)$

B2 tip kirişinin net uzunluğu $5.75 \Rightarrow L_{\mathrm{s}}=5.75 / 2=2.875 \mathrm{~m}$

$L_{\mathrm{p}}=\mathrm{h} / 2=0.50 / 2=0.25 \mathrm{~m}$

$d_{\mathrm{b}}=0.015 \mathrm{~mm}$

$\theta_{\mathrm{p}}^{(\mathrm{GÖ})}=\frac{2}{3}\left((0.1865-0.00807) 0.25\left(1-0.5 \frac{0.25}{2.875}\right)+4.5 \times 0.1865 \times 0.015\right)$

$\theta_{\mathrm{p}}^{(\mathrm{GÖ})}=0.036839 \mathrm{rad}$

$\theta_{\mathrm{p}}^{(\mathrm{KH})}=0.75 \theta_{\mathrm{p}}^{(\mathrm{GO})}$

$\theta_{\mathrm{p}}^{(\mathrm{KH})}=0.75 \times 0.036839=0.02762925 \mathrm{rad}$

$\theta_{\mathrm{p}}^{(\mathrm{SH})}=0$

\subsubsection{Kolon ve betonarme perde kesitlerinin plastik mafsal özelliklerinin belirlenmesi}

Kolon ve betonarme perdelerde de kirişlere benzer olarak enine ve boyuna donatı, kesit boyutları ve açıklık mesafesine göre tip kesit adlandırılması yapılmıştır. Kolonlar için kesit tipleri C harfi ile betonarme perdeler için $\mathrm{W}$ ile oluşturulmuştur. İncelenen binada 3 tip kolon, 2 tip betonarme perde kesiti bulunmaktadır. Kolon ve betonarme perde tip kesitlerinin özelikleri Tablo 7'de kesitleri ise Şekil 5'te verilmiştir.

Tablo 7. Kolon ve betonarme perde kesitlerinin özellikleri

\begin{tabular}{|l|l|l|l|}
\hline Kesit Tipi & Kolonlar & $\mathbf{b} \mathbf{x} \mathbf{h}$ & Sıklaştırma Bölgesi Enine Donatısı \\
\hline C1 & S101-S102-S107-S110-S115-S116 & $30 \times 70$ & $8 \varnothing / 8$ \\
\hline C2 & S104-S105-S112-S113 & $40 \times 70$ & $8 \varnothing / 8$ \\
\hline C3 & S103-S106-S111-S114 & $130 \times 30$ & $8 \varnothing / 8$ \\
\hline W1 & P101-P102 & $235 \times 30$ & $8 \varnothing / 8$ \\
\hline W2 & P103-P104-P105-P106 & $30 \times 190$ & $8 \varnothing / 8$ \\
\hline
\end{tabular}




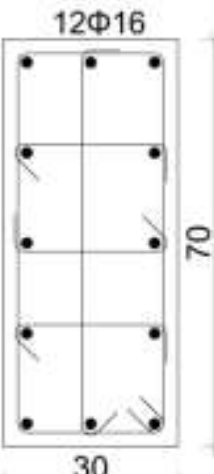

C1 tip kesiti

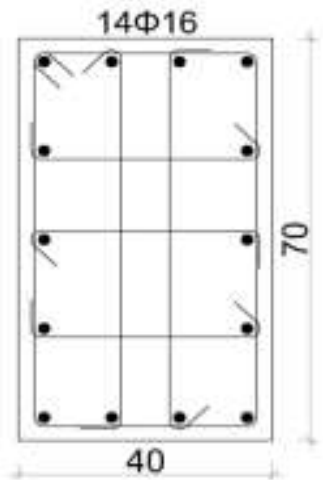

C2 tip kesiti

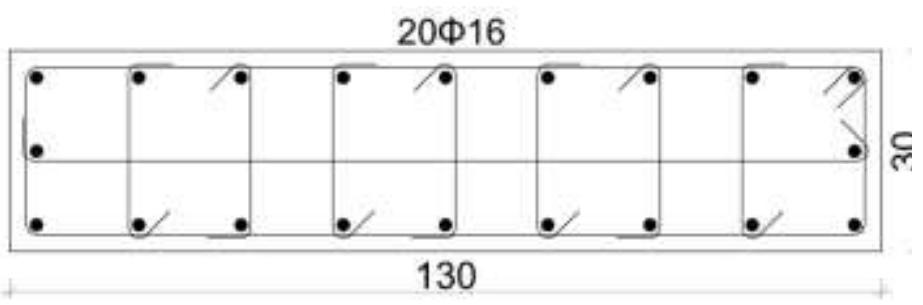

C3 tip kesiti

Şekil 5a. Kolon tip kesitleri

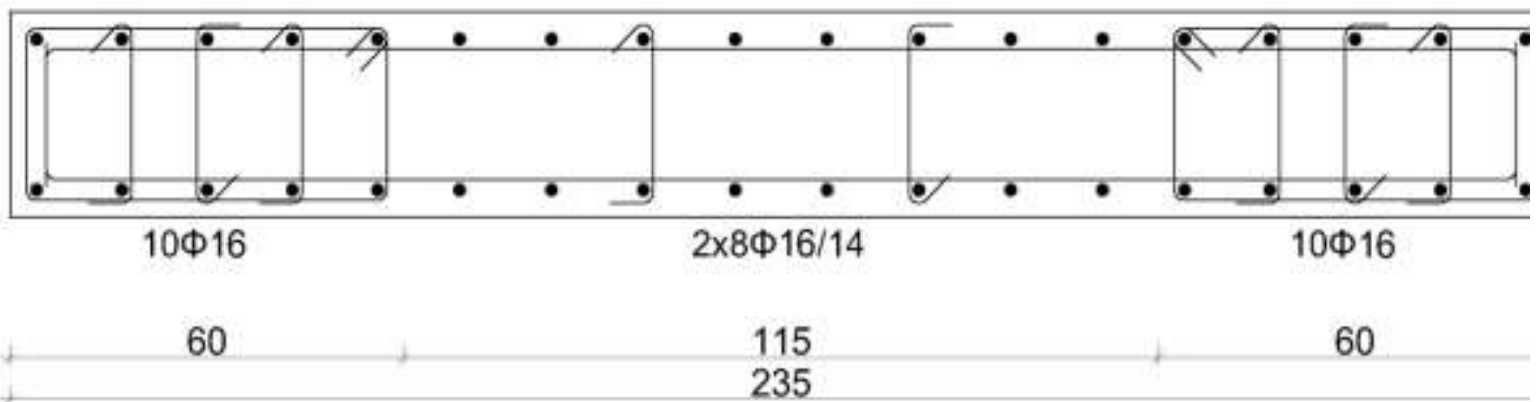

W1 tip kesiti

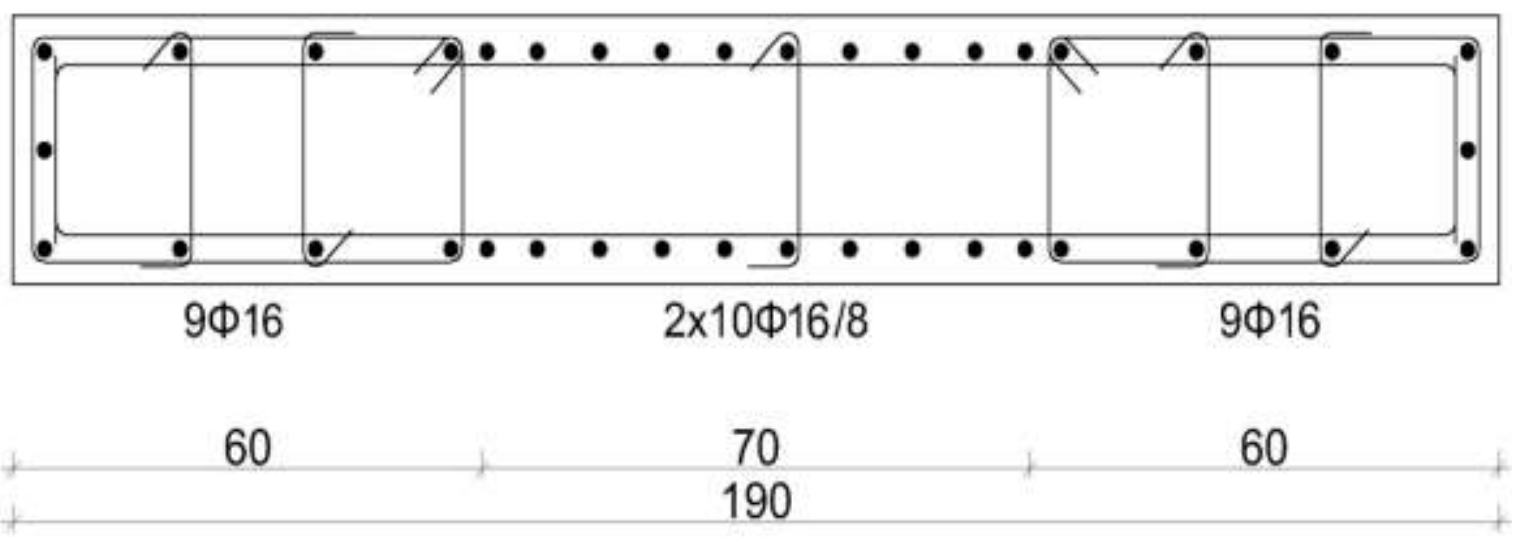

W2 tip kesiti

Şekil 5b. Betonarme perde tip kesitleri

Kolon ve betonarme perdelerin moment eğrilik bağıntılılarının elde edilmesinde kirişlerden farklı olarak eksenel yük seviyesi de dikkate alınmıştır. Kesitlerin moment-eğrilik analizleri 9 adet eksenel yük altında yapılmıştır. Moment-eğrilik analizleri $0^{\circ}$ ve $90^{\circ}$ olmak üzere 2 doğrultu için yapılmıştır. M2 eğilme doğrultusu için $0^{0}$ dan elde edilen moment-eğrilik değerleri, M3 eğilme doğrultusu için $90^{\circ}$, dan elde edilen moment-eğrilik değerleri kullanılmıştır. C1 tip kolon kesiti için yapılan moment eğrilik analizi sonucu elde edilen akma eğrilikleri $\left(\phi_{\mathbf{y}}\right)$, göçme öncesi eğrilikler $\left(\phi_{\mathbf{u}}\right)$, akma momentleri $\left(\mathbf{M}_{\mathbf{y}}\right)$ ve göçme öncesi momentler $\left(\mathbf{M}_{\mathbf{u}}\right)$ eksenel yük seviyesi ve akma yüzeyine bağl1 olarak Tablo 8'de verilmiştir. 
Tablo 8. C1 tip kolonun moment eğrilik analizi sonuçları

\begin{tabular}{|c|c|c|c|c|c|c|c|}
\hline Kolon Tipi & $\mathrm{P}(\mathrm{kN})$ & Akma Yüzeyi & $\begin{array}{l}\phi_{\mathrm{y}} \\
\left(\mathrm{m}^{-1}\right)\end{array}$ & $\begin{array}{c}\mathrm{M}_{\mathrm{y}} \\
(\mathrm{kNm})\end{array}$ & $\begin{array}{l}\phi_{\mathrm{u}} \\
\left(\mathrm{m}^{-1}\right)\end{array}$ & $\begin{array}{r}\mathrm{M}_{\mathrm{u}} \\
(\mathrm{kNm})\end{array}$ & $\mathrm{L}_{\mathrm{p}}$ \\
\hline \multirow{18}{*}{$\mathrm{C} 1$} & \multirow{2}{*}{-7395} & $0^{0}$ & 0.01130 & 309.9739 & 0.0538 & 191.0999 & 0.15 \\
\hline & & $90^{\circ}$ & 0.00462 & 742.3118 & 0.0218 & 498.7976 & 0.35 \\
\hline & \multirow{2}{*}{-6660} & $0^{0}$ & 0.01270 & 354.8609 & 0.0588 & 258.9297 & 0.15 \\
\hline & & $90^{\circ}$ & 0.00513 & 844.2299 & 0.0237 & 660.5676 & 0.35 \\
\hline & \multirow{2}{*}{-5465} & $0^{0}$ & 0.01550 & 402.6571 & 0.0696 & 342.0784 & 0.15 \\
\hline & & $90^{0}$ & 0.00622 & 947.5434 & 0.0283 & 833.8808 & 0.35 \\
\hline & \multirow{2}{*}{-4207} & $0^{0}$ & 0.01970 & 426.003 & 0.0901 & 368.5381 & 0.15 \\
\hline & & $90^{0}$ & 0.00784 & 989.0779 & 0.0354 & 906.8484 & 0.35 \\
\hline & \multirow{2}{*}{-2740} & $0^{0}$ & 0.01930 & 387.7868 & 0.1233 & 358.2386 & 0.15 \\
\hline & & $90^{0}$ & 0.00773 & 903.8282 & 0.0496 & 871.159 & 0.35 \\
\hline & \multirow{2}{*}{-2078} & $0^{0}$ & 0.01740 & 341.1767 & 0.1592 & 332.1316 & 0.15 \\
\hline & & $90^{\circ}$ & 0.00741 & 820.0568 & 0.0622 & 801.6431 & 0.35 \\
\hline & \multirow{2}{*}{-1352} & $0^{0}$ & 0.01640 & 291.697 & 0.2255 & 288.9669 & 0.15 \\
\hline & & $90^{\circ}$ & 0.00714 & 701.7643 & 0.0789 & 695.2434 & 0.35 \\
\hline & \multirow{2}{*}{-643.388} & $0^{0}$ & 0.01570 & 230.6674 & 0.3682 & 233.4912 & 0.15 \\
\hline & & $90^{\circ}$ & 0.00703 & 562.7579 & 0.1122 & 569.9397 & 0.35 \\
\hline & \multirow{2}{*}{226.1852} & $0^{0}$ & 0.01480 & 135.1166 & 0.341 & 138.3892 & 0.15 \\
\hline & & $90^{\circ}$ & 0.00728 & 342.0772 & 0.1318 & 359.3741 & 0.35 \\
\hline
\end{tabular}

Moment eğrilik analiz sonuçlarından faydalanarak kesit hasar sınırlarına tekabül eden plastik dönme sınır değerleri hesaplanmıştır. C1 tipi kesitinin $0^{0}$ akma yüzeyi için $7395 \mathrm{kN}$ eksenel yük altında plastik dönme sınır değerleri aşağıda verildiği gibi hesaplanmıştır.

$\theta_{\mathrm{p}}^{(\mathrm{GÖ})}=\frac{2}{3}\left(\left(\phi_{\mathrm{u}}-\phi_{\mathrm{y}}\right) L_{\mathrm{p}}\left(1-0.5 \frac{L_{\mathrm{p}}}{L_{\mathrm{s}}}\right)+4.5 \phi_{\mathrm{u}} d_{\mathrm{b}}\right)$

$L_{\mathrm{s}}=2.30 / 2=1.15 \mathrm{~m}$

$L_{\mathrm{p}}=\mathrm{h} / 2=0.30 / 2=0.15 \mathrm{~m}$

$d_{\mathrm{b}}=0.016$

$\theta_{\mathrm{p}}^{(\mathrm{GÖ})}=\frac{2}{3}\left((0.0538-0.01130) 0.15\left(1-0.5 \frac{0.15}{1.15}\right)+4.5 \times 0.0538 \times 0.016\right)$

$\theta_{\mathrm{p}}^{(\mathrm{GÖ})}=0.006555$

$\theta_{\mathrm{p}}^{(\mathrm{KH})}=0.75 \theta_{\mathrm{p}}^{(\mathrm{GO})}$

$\theta_{\mathrm{p}}^{(\mathrm{KH})}=0.75 \times 0.006555=0.0049162$

$\theta_{\mathrm{p}}^{(\mathrm{SH})}=0$

\subsubsection{Plastik mafsal kesitlerinin oluşturulması}

Her bir taşıyıcı elemanın plastik mafsal özellikleri belirlendikten sonra kiriş, kolon ve betonarme perdeler için plastik mafsal kesitleri oluşturulmuştur. Kirişler için eksenel kuvvet ihmal edildiğinden bu kesitlerin modellenmesinde M3 plastik mafsalı kullanılmıştır. Kolon ve betonarme perde kesitlerine eğilme momenti ile birlikte eksenel kuvvet de etki ettiği için bu kesitler için P-M2-M3 plastik mafsalı kullanılmıştır. Kolon ve betonarme perde kesitleri için ayrıca $0^{0}, 45^{0}$ ve $90^{\circ}$ olmak üzere 3 adet akma yüzeyi tanımlanması da yapılmıştır. Plastik mafsal kesitleri tanımlandıktan sonra bu kesitlerin binanın 3D modelinde bulunan ilgili kesitlere atanmıştır. Kolon ve kiriş elemanlarının her iki ucuna plastik mafsal atanmıştır. Perdelerde ise sadece elemanın alt ucuna plastik mafsal atanmıştır. 


\subsection{Etkin Kesit Rijitliklerinin Hesaplanması}

TBDY (2018) [6]'e göre yeni yapılacak binalarda yığılı plastik davranışına göre modellenen kolon, kiriş ve betonarme perdelerin etkin kesit rijitlikleri Denklem 1'e göre belirlenmektedir.

$(E I)_{\mathrm{e}}=\frac{M_{\mathrm{y}}}{\theta_{\mathrm{y}}} \frac{L_{\mathrm{s}}}{3}$

Burada, $M_{\mathrm{y}}$; çubuk elemanların uç bölgelerindeki plastik mafsalların etkin akma momentlerinin ortalamasını, $\theta_{\mathrm{y}}$; çubuk elamanların uç bölgelerindeki plastik mafsalların akma dönmelerinin ortalamasını ifade etmektedir. Taşıyıcı elemanların plastik mafsallarının etkin akma momentleri $\left(M_{\mathrm{y}}\right)$ moment eğrilik analizi ile belirlenmişti. Taşıııcı elemanların plastik mafsallarının akma dönmeleri $\left(\theta_{\mathrm{y}}\right)$ ise Denklem 2 ile belirlenmektedir.

$\theta_{\mathrm{y}}=\frac{\phi_{\mathrm{y}} L_{\mathrm{s}}}{3}+0.0015 \eta\left(1+1.5 \frac{h}{L_{\mathrm{s}}}\right)+\frac{\phi_{\mathrm{y}} d_{\mathrm{b}} f_{\mathrm{ye}}}{8 \sqrt{f_{\mathrm{ce}}}}$

Burada, $\phi_{\mathrm{y}}$ plastik mafsal kesitindeki etkin akma eğrliğini ifade etmektedir. $\eta$ katsayısı ise kiriş ve kolonlarda 1 , perdelerde 0.5 alınmaktadır.

\section{- $\quad$ Kirișlerin Etkin Kesit Rijitliği}

B2 tip kiriş kesitinin etkin kesit rijitlik çarpanı aşağıda hesaplanmıştır. Kirişin moment eğrilik analizi sonuçları Tablo 6' dan alınmıştır.

$0^{0}$ Akma yüzeyi için;

Kirişin net boyu $5.75 \mathrm{~m} \Rightarrow L_{\mathrm{s}}=5.75 / 2=2.875 \mathrm{~m}$

$M_{\mathrm{y}}=173.4675 \mathrm{kNm}$

$\phi_{\mathrm{y}}=0.00807 \mathrm{rad} / \mathrm{m}$

$d_{\mathrm{b}}=0.0015 \mathrm{~m}$

$\theta_{\mathrm{y}}=\frac{\phi_{\mathrm{y}} L_{\mathrm{s}}}{3}+0.0015 \eta\left(1+1.5 \frac{h}{L_{\mathrm{s}}}\right)+\frac{\phi_{\mathrm{y}} d_{\mathrm{b}} f_{\mathrm{ye}}}{8 \sqrt{f_{\mathrm{ce}}}}$

$\theta_{\mathrm{y}}=\frac{0.00807 \times 2.875}{3}+0.0015 \times 1\left(1+1.5 \frac{0.5}{2.875}\right)+\frac{0.00807 \times 0.0015 \times 504}{8 \sqrt{45.5}}$

$\theta_{\mathrm{y}}=0.01075 \mathrm{rad}$

$180^{\circ}$ Akma yüzeyi için;

$M_{\mathrm{y}}=187.4965 \mathrm{kNm}$

$\phi_{\mathrm{y}}=0.00823 \mathrm{rad} / \mathrm{m}$

$d_{\mathrm{b}}=0.0015 \mathrm{~m}$

$\theta_{\mathrm{y}}=\frac{0.00823 \times 2.875}{3}+0.0015 \times 1\left(1+1.5 \frac{0.5}{2.875}\right)+\frac{0.00823 \times 0.0015 \times 504}{8 \sqrt{45.5}}$

$\theta_{\mathrm{y}}=0.01093 \mathrm{rad}$

$M_{\mathrm{y}, \mathrm{ort}}=\frac{173.4375+187.4965}{2}=180.482 \mathrm{kNm}$

$\theta_{\mathrm{y}, \mathrm{ort}}=\frac{0.01075+0.01093}{2}=0.01084 \mathrm{rad}$

$(E I)_{\mathrm{e}}=\frac{180.482}{0.01084} \times \frac{2.875}{3}=15954.78 \mathrm{kNm}^{2}$

Kesit Brüt Rijitliği $=(E I)_{\mathrm{o}}=86529.32 \mathrm{kNm}^{2}$ 
$\frac{(E I)_{\mathrm{e}}}{(E I)_{\mathrm{o}}}=0.184386$

Diğer tip kiriş kesitleri için elde edilen etkin kesit rijitlik çarpanları Şekil 6'da verilmiştir.

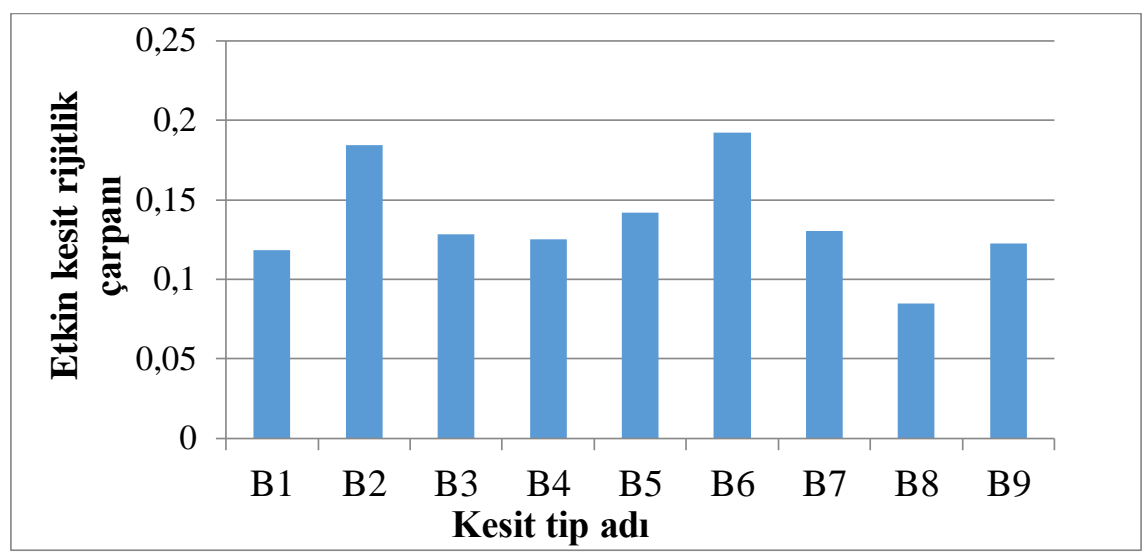

Şekil 6. Kirişlerin etkin kesit rijitlik çarpanları

- $\quad$ Kolon ve betonarme perdelerin etkin kesit rijitliği

Düşey taşıyıcı elemanlardın etkin kesit rijtiliklerinin hesabı için ise bina önce $G+\mathrm{n} Q$ kombinasyonu altında analize tabi tutulmuştur. Burada; G sabit yükleri, Q hareketli yükleri, $\mathrm{n}$ hareketli yük azaltma katsayısını göstermektedir. Her bir düşey taşıyıcı elemanda bu yük birleşimi altında meydana gelen eksenel yük değeri belirlenmiştir. Taşıyıcı elemanların plastik mafsallarının etkin akma momentleri $\left(M_{\mathrm{y}}\right)$ ve plastik mafsal kesitindeki etkin akma eğrilikleri $\left(\phi_{\mathrm{y}}\right)$ elde edilen bu eksenel yük altında yapılan Moment eğrilik analizleri ile belirlenmiştir. C3 Tip kolon kesiti içinde yer alan S103S106-S111-S114 kolonları ile S108-S109 kolonlarının yapı içindeki konumları farklı olduğundan bu kolonlardan $G+\mathrm{n} Q$ yük birleşimi altında elde edilecek olan eksenel yük değerleri farklı olacaktır. Eksenel yük değerleri farklı olması da etkin kesit rijitlik çapanını da değiştirecektir. Bu yüzden etkin kesit rijitliklerinin belirlenmesi aşamasında S103-S106-S111-S114 kolonları C3_1 tip kolon olarak, S108-S109 kolonları ise C3_2 tip kolon olarak adlandırılmıştır. $G+\mathrm{n} Q$ yük birleşimi altında her kat için tip kesite bağlı olarak elde edilen eksenel yük değerleri Tablo 9'da verilmiştir.

Tablo 9. G $+0.3 \mathrm{Q}$ yük birleșimi altında kolon/perdelerde oluşan eksenel kuvvetler $(\mathrm{kN})$

\begin{tabular}{|l|l|l|l|l|l|l|l|l|}
\hline Kesit Tipi & 1. Kat & 2. Kat & 3. Kat & 4. Kat & 5. Kat & 6. Kat & 7. Kat & 8. kat \\
\hline C1 & -1222.5 & -1061.5 & -902.12 & -743.65 & -586.04 & -429.09 & -272.52 & -116.75 \\
\hline C2 & -2040.5 & -1768.5 & -1502.4 & -1240.1 & -980.93 & -724.48 & -469.64 & -217.45 \\
\hline C3_1 & -1250.3 & -1096.7 & -939.89 & -781.13 & -620.65 & -458.79 & -296.16 & -131.85 \\
\hline C3_2 & -1443.2 & -1261.1 & -1078.0 & -894.09 & -709.50 & -524.4 & -338.91 & -153.20 \\
\hline W1 & -2067.5 & -1812.3 & -1554.4 & -1293.8 & -1031.1 & -766.85 & -501.32 & -234.95 \\
\hline W2 & -1022.1 & -898.50 & -771.61 & -642.85 & -512.43 & -380.7 & -248.17 & -114.22 \\
\hline
\end{tabular}

C1 tipi bir kolonun 1.kat için $0^{0}$ Akma yüzeyinin etkin kesit rijitlik çarpanının hesaplanması aşağıda yapılmıştır. Kolonun etkin akma momentleri $\left(M_{\mathrm{y}}\right)$ ve etkin akma eğrilikleri $\left(\phi_{\mathrm{y}}\right) 1222.5 \mathrm{kN}$ eksenel yük altında yapılan moment eğrilik analizleri ile belirlenmiştir

Kolonun net boyu $2.30 \mathrm{~m} \Rightarrow L_{\mathrm{s}}=2.30 / 2=1.15 \mathrm{~m}$

$M_{\mathrm{y}}=281.7803 \mathrm{kNm}$

$\phi_{\mathrm{y}}=0.01630 \mathrm{rad} / \mathrm{m}$

$d_{\mathrm{b}}=0.0016 \mathrm{~m}$

$\theta_{\mathrm{y}}=\frac{\phi_{\mathrm{y}} L_{\mathrm{s}}}{3}+0.0015 \eta\left(1+1.5 \frac{h}{L_{\mathrm{s}}}\right)+\frac{\phi_{\mathrm{y}} d_{\mathrm{b}} f_{\mathrm{ye}}}{8 \sqrt{f_{\mathrm{ce}}}}$ 
$\theta_{\mathrm{y}}=\frac{0.01630 \times 2.875}{3}+0.0015 \times 1\left(1+1.5 \frac{0.3}{1.15}\right)+\frac{0.01630 \times 0.0016 \times 504}{8 \sqrt{45.5}}$

$\theta_{\mathrm{y}}=0.010771 \mathrm{rad}$

$(E I)_{\mathrm{e}}=\frac{281.7803}{0.010771} \times \frac{1.15}{3}=10028.3 \mathrm{kNm}^{2}$

$\mathrm{X}$ doğrultusu Kesit Brüt Rijitliği $=(E I)_{\mathrm{x}}=52332.93 \mathrm{kNm}^{2}$

$\frac{(E I)_{\mathrm{e}}}{(E I)_{\mathrm{x}}}=\mathbf{0 . 1 9 2}$

Diğer tip kolon ve betonarme perde kesitleri için elde edilen etkin kesit rijitlik çarpanları Şekil 7'de verilmiştir.

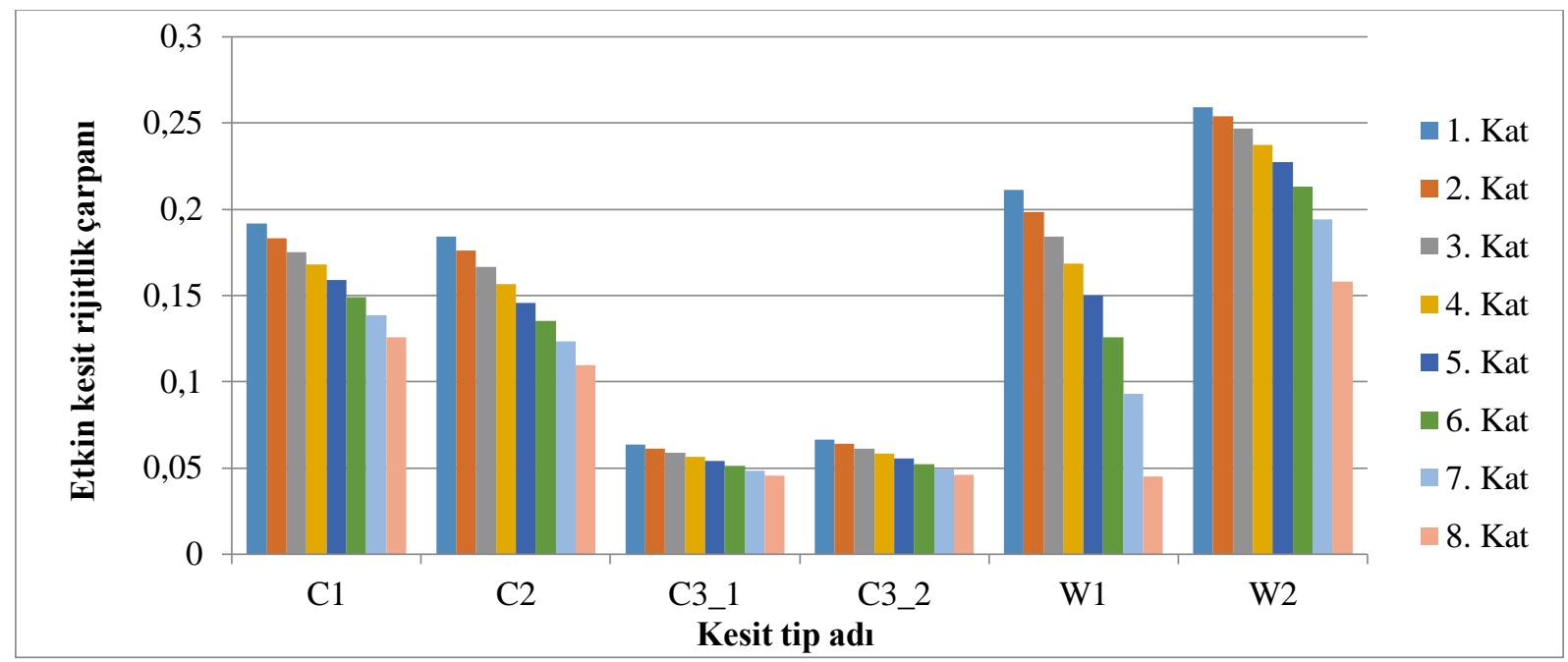

Şekil 7a. Kolon ve perdelerin X doğrultusu için elde edilen etkin kesit rijitlik çarpanları

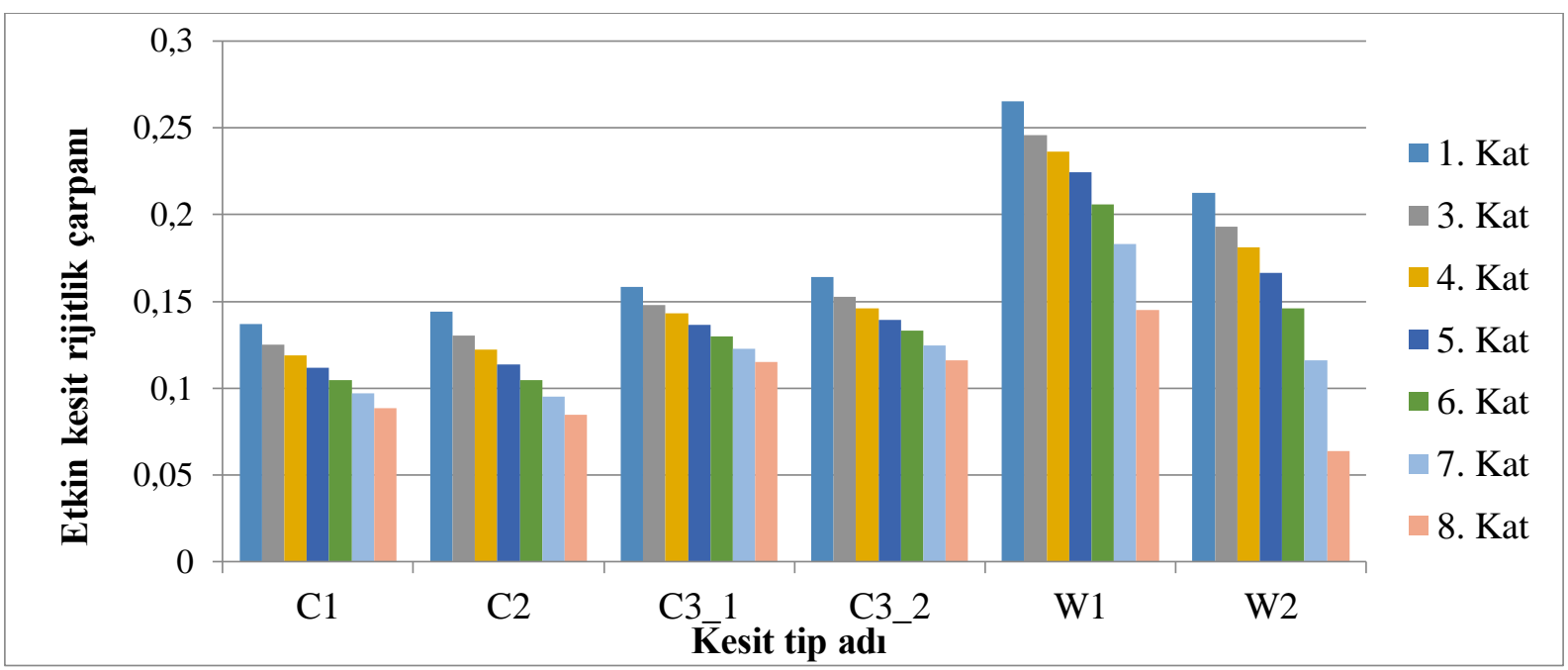

Şekil 7b. Kolon ve perdelerin Y doğrultusu için elde edilen etkin kesit rijitlik çarpanları

\subsection{Tek Modlu Statik İtme Analizinin Tanımlanması}

TBDY 2018 [6]'e göre statik itme analizinden önce statik düşey yüklerin hesaplanarak yapıya artımsal olarak uygulanması gerekmektedir. Doğrusal olmayan statik hesap olan bu yöntemle bulunan şekil değiştirme ve iç kuvvet değerleri yatay deprem hesabının başlangıç adımı olarak kullanılmalıdır. Statik itme analizinin başlangıç adımı olan statik düşey yükler Denklem 3 ile hesaplanmaktadır. 
$G+\mathrm{n} Q+0.3 E_{\mathrm{d}}^{(\mathrm{Z})}$

Burada, $E_{\mathrm{d}}^{(\mathrm{Z})}$ ise düşey deprem etkisini ifade etmektedir. Düşey deprem etkisi $\left(E_{\mathrm{d}}^{(\mathrm{Z})}\right)$ Denklem 4 ile elde edilmektedir.

$E_{\mathrm{d}}^{(\mathrm{Z})}=(2 / 3) S_{D S} G$

Burada; $S_{D S}$ binanın kısa periyot tasarım spektral ivme katsayısını göstermektedir. Binanın bulunduğu konum, yer hareket düzeyi ve zemin sınıfına göre Türkiye Deprem Tehlike Haritaları İnteraktif Web Uygulamasından alınmaktadır. Denklem 4 ile elde edilen $E_{\mathrm{d}}^{(\mathrm{Z})}$, Denklem 3'te yerine koyulursa Denklem 5 elde edilir.

$G\left(1+0.2 \times S_{D S}\right)+\mathrm{n} Q$

Konut türü binalar için $\mathrm{n}$ değeri 0.3 alınmalıdır. Kısa periyot tasarım spektral ivme katsayısı $\left(S_{D S}\right)$ için ise hedef performans seviyesi için gerekli yer hareket düzeyinin belirlenmesi gerekmektedir. Yeni yapılacak bir binanın hedef performans seviyesi Tablo 2'e göre belirlenmektedir. Tablo 2'de yer alan Deprem Tasarım sınıfı ise DD-2 deprem düzeyine için $S_{D S}$ değerine göre belirlenmektedir. Binanın bulunduğu konum, DD-2 deprem yer hareket düzeyi ve ZD zemin sınıfına göre Türkiye Deprem Tehlike Haritaları İnteraktif Web Uygulamasından $S_{D S}=0.973$ olarak elde edilmiştir. TBDY 2018 [6] de yer alan Tablo 3.2'e göre konut türü bir binanın $S_{D S}=0.973$ için DTS=1 olmaktadır. Bu durumda Tablo 2'e göre binanın hedef performans seviyesi DTS=1 için DD-2 deprem yer hareket düzeyine göre Kontrolü Hasar(KH)'dır. DD-2 deprem düzeyi için $S_{D S}$ değeri ile n değerleri Denklem 5 'te yerlerine yazılırsa Denklem 6 elde edilir.

$1.195 G+0.3 Q$

Denklem 6.14'de yer alan G ve Q yüklerinin önündeki katsayılar SAP 2000'de tanımlanan statik düşey yüklemenin scale faktörleri olarak kullanılmıştır

Sabit tek modlu itme analizi, deprem doğrultusunda hakim titreşim mod şekli ile orantılı olacak şekilde yük artımı prensibine dayanmaktadır. İncelenen binanın her bir katına, ilgili doğrultunun mod şekli genliği ile katlara ait kütlelerin çarpımıyla elde edilen değerlere göre yatay yükler uygulanmış, yapılan statik itme analizi sonucu Şekil 8'de verilen kapasite eğrileri elde edilmiştir.

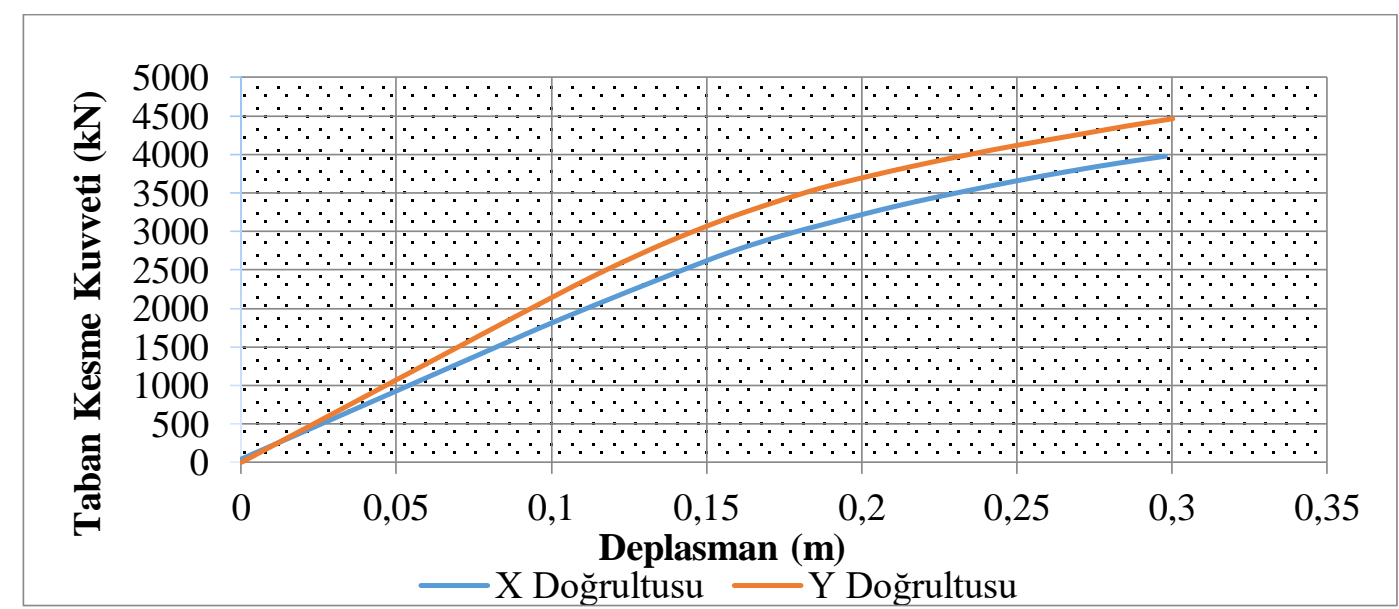

Şekil 8. Binanın her iki doğrultusunun kapasite eğrileri

\subsection{Hedef Deplasman Seviyesinin Belirlenmesi}

Binanın taşıyıcı elemanlarında meydana gelecek hasarların belirlenmesi için binanın her iki doğrultuda hedef deplasman seviyesine kadar statik itme analizine tabi tutulmasi gerekir. Hedef deplasman seviyesinin belirlenmesi için kapasite eğrisi ile talep spektrumu aynı grafikte kesiştirilmelidir. Kapasite 
eğrisi ile talep spektrumunun eksen takımları aynı olmadığından öncelikle kapasite eğrisinin eksen takımının koordinatlarının dönüştürülmesi gereklidir. Kapasite eğrisinin eksen takımının koordinatlarının değiştirilmesi ile modal kapasite eğrisi oluşturulur. Eksen takımının dönüştürülmesi ile spektral ivme $(\mathrm{Sa})$ ve spektral yer değiştirme $(\mathrm{Sd})$ eksenleri elde edilir. Eksen dönüştürme işlemi hakkında detaylı bilgilendirme TBDY 2018 [6] 5B.1. maddesinde bulunmaktadır. Eksen takımının dönüştürülmesi için gerekli parametreler Tablo 10'da verilmiştir.

Tablo 10. Modal kapasite eğrisinin elde edilmesi için gerekli veriler

\begin{tabular}{|c|c|c|c|c|c|c|c|}
\hline Yön & Kat & $\begin{array}{c}\text { Kat Kütlesi } \\
\mathrm{kNs}^{2} / \mathrm{m}\end{array}$ & $\begin{array}{l}\text { Mod şekli genliği } \\
\text { (m) }\end{array}$ & $\begin{array}{c}\mathrm{M}_{1} \\
\left(\mathrm{kNs}^{2} \mathrm{~m}\right)\end{array}$ & $\begin{array}{c}\mathrm{L}_{\mathrm{x} 1} \\
\left(\mathrm{kNs}^{2)}\right.\end{array}$ & $\begin{array}{l}\Gamma_{1}^{(X)} \\
(1 / \mathrm{m})\end{array}$ & $\begin{array}{c}\mathrm{M}_{\mathrm{x} 1} \\
\left(\mathrm{kNs}^{2} / \mathrm{m}\right)\end{array}$ \\
\hline \multirow{8}{*}{ X } & 1 & 4026.19 & 0.001461 & \multirow{8}{*}{1.024} & \multirow{8}{*}{49.212} & \multirow{8}{*}{48.065} & \multirow{8}{*}{2365.345} \\
\hline & 2 & 4026.19 & 0.004827 & & & & \\
\hline & 3 & 4026.19 & 0.00919 & & & & \\
\hline & 4 & 4026.19 & 0.013903 & & & & \\
\hline & 5 & 4026.19 & 0.018483 & & & & \\
\hline & 6 & 4026.19 & 0.022573 & & & & \\
\hline & 7 & 4026.19 & 0.02592 & & & & \\
\hline & 8 & 3340.118 & 0.028387 & & & & \\
\hline \multirow{8}{*}{$\mathrm{Y}$} & 1 & 4026.19 & 0.001556 & \multirow{8}{*}{1.021} & \multirow{8}{*}{49.444} & \multirow{8}{*}{48.438} & \multirow{8}{*}{2394.989} \\
\hline & 2 & 4026.19 & 0.005069 & & & & \\
\hline & 3 & 4026.19 & 0.009513 & & & & \\
\hline & 4 & 4026.19 & 0.014204 & & & & \\
\hline & 5 & 4026.19 & 0.018667 & & & & \\
\hline & 6 & 4026.19 & 0.022572 & & & & \\
\hline & 7 & 4026.19 & 0.025702 & & & & \\
\hline & 8 & 3340.118 & 0.027953 & & & & \\
\hline
\end{tabular}

Modal kapasite eğrisinden çizilen başlangıç teğetinin talep spektrumunu kestiği nokta elastik tasarım spektral yerdeğiştirme Sde (T1) olarak ifade edilmektedir. X ve Y doğrultularının her biri için elastik tasarım spektral yer değiştirmeler elde edilmiştir. Talep ve kapasite spektrumlarının ikisi de elastik tabanlı olduğundan modal kapasite eğrisinden çizilen başlangıç teğetinin talep spektrumunu kestiği noktayı her zaman doğrusal olmayan spektral yer değiştirme Sdi (T1) olarak ifade etmek doğru olmayacaktır. Denklem 7 ile de anlaşılacağı üzere elastik tasarım spektral yerdeğiştirmeden doğrusal olmayan spektral yer değiştirmeye geçiş için $C_{R}$ dönüştürme katsayısı kullanılmaktadır.

$\mathrm{S}_{\mathrm{di} 1}=\mathrm{C}_{\mathrm{R} 1} \mathrm{~S}_{\mathrm{de} 1}$

$\mathrm{C}_{\mathrm{R}}$ dönüştürme katsayısı ile ilgi detaylı işlemler TBDY 2018 [6]'in 5B.3. maddesinde bulunmaktadır. $\mathrm{X}$ ve $\mathrm{Y}$ doğrultularının her ikisinde de hakim titreşim periyod $\mathrm{S}_{\mathrm{DS}} / \mathrm{S}_{\mathrm{D} 1}$ değerinden büyük olduğu için yönetmelik gereği $C_{R}$ dönüştürme katsayısı her iki doğrultuda da 1 alınmıştır. Bu durumda her iki doğrultuda da elastik tasarım spektral yer değiştirme doğrusal elastik olmayan spektral yerdeğiştirmeye eşit çıkmıştır $\left[d_{1, \max }^{(X)}=S_{d i}\left(T_{1}\right)=S_{d e}\left(T_{1}\right)\right]$. Elde edilen $d_{1, \text { max }}^{(X)}$ değeri Denklem 8'de yerine koyularak hedef yerdeğiştirme istemi $\left(u_{N x 1}^{(X)}\right)$ elde edilmiştir.

$u_{N x 1}^{(X)}=\phi_{N x 1} \Gamma_{1}^{(X)} d_{1, \max }^{(X)}$

$\mathrm{X}$ ve Y doğrultularının hedef deplasman istemlerinin elde edilmesi için gerekli yardımcı veriler ile bu verilerin kullanılmasıyla elde edilen hedef deplasmanlar istemleri Tablo 11'de verilmiştir.

Tablo 11. Hedef deplasman istemleri

\begin{tabular}{|l|l|l|c|c|l|}
\hline Doğrultu & $\mathrm{S}_{\mathrm{de}}\left(\mathrm{T}_{1}\right)(\mathrm{mm})$ & $d_{1, \max }^{(X)}(\mathrm{mm})$ & $\phi_{N x 1}$ & $\Gamma_{1}^{(X)}$ & $u_{N x 1}^{(X)}(\mathrm{mm})$ \\
\hline $\mathrm{X}$ & 109.6 & 109.6 & 0.028387 & 48.065 & 149 \\
\hline $\mathrm{Y}$ & 100.19 & 100.19 & 0.027953 & 48.438 & 135 \\
\hline
\end{tabular}


$\mathrm{X}$ ve Y doğrultularının hedef deplasman istemlerinin elde edilmesinde kullanılan grafikler Şekil 9'da verilmiştir.

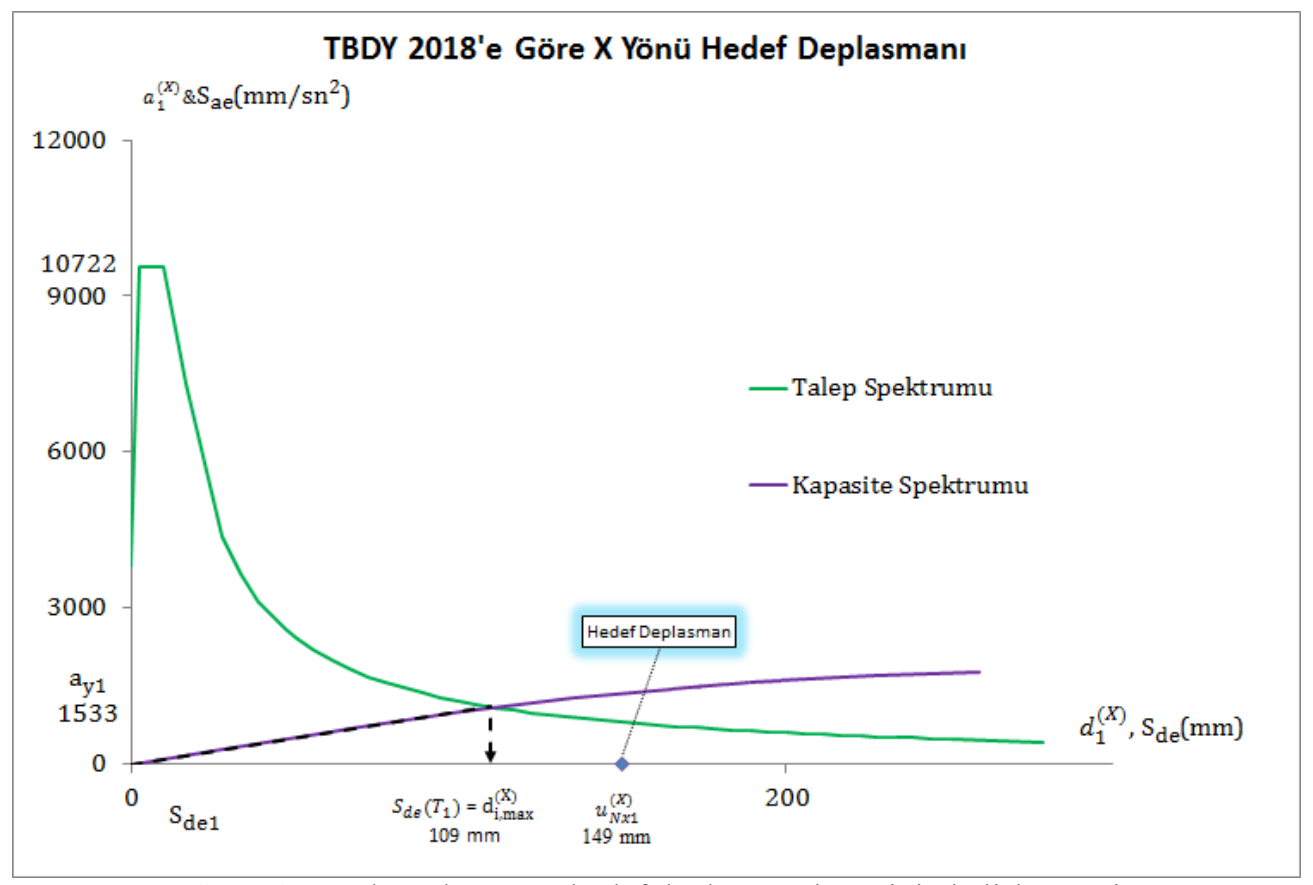

Şekil 9a. X doğrultusunun hedef deplasman isteminin belirlenmesi

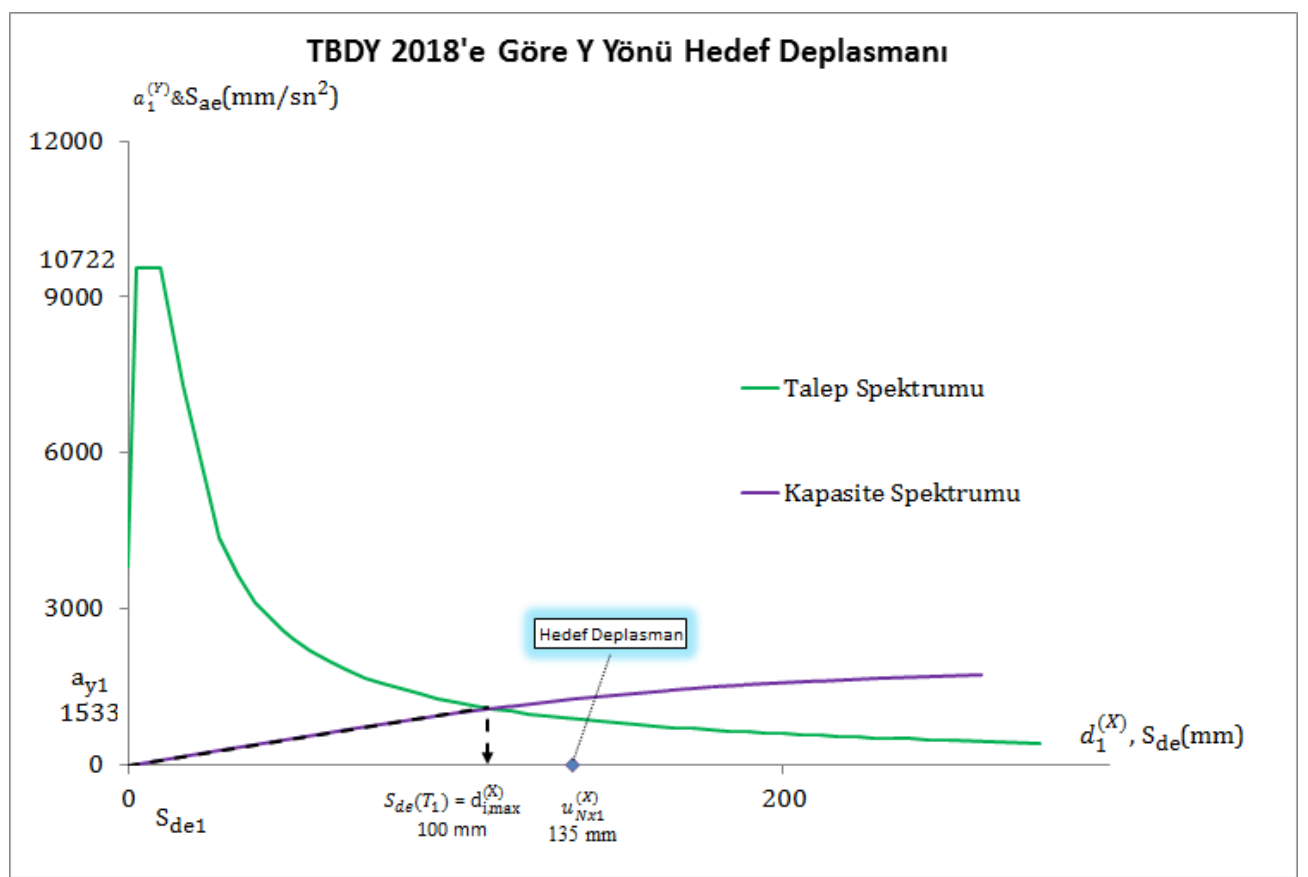

Şekil 9b. Y doğrultusunun hedef deplasman isteminin belirlenmesi

\subsection{Tek Modlu Statik İtme Analizinin Yapılması}

İncelenen binanın $\mathrm{X}$ ve $\mathrm{Y}$ doğrultularının her biri için hedef deplasman seviyesine kadar sabit tek modlu statik itme analizi yapılmıştır. Böylece her bir taşıyıcı elemanda meydana gelen hasarla belirlenmiştir (Şekil 10). 


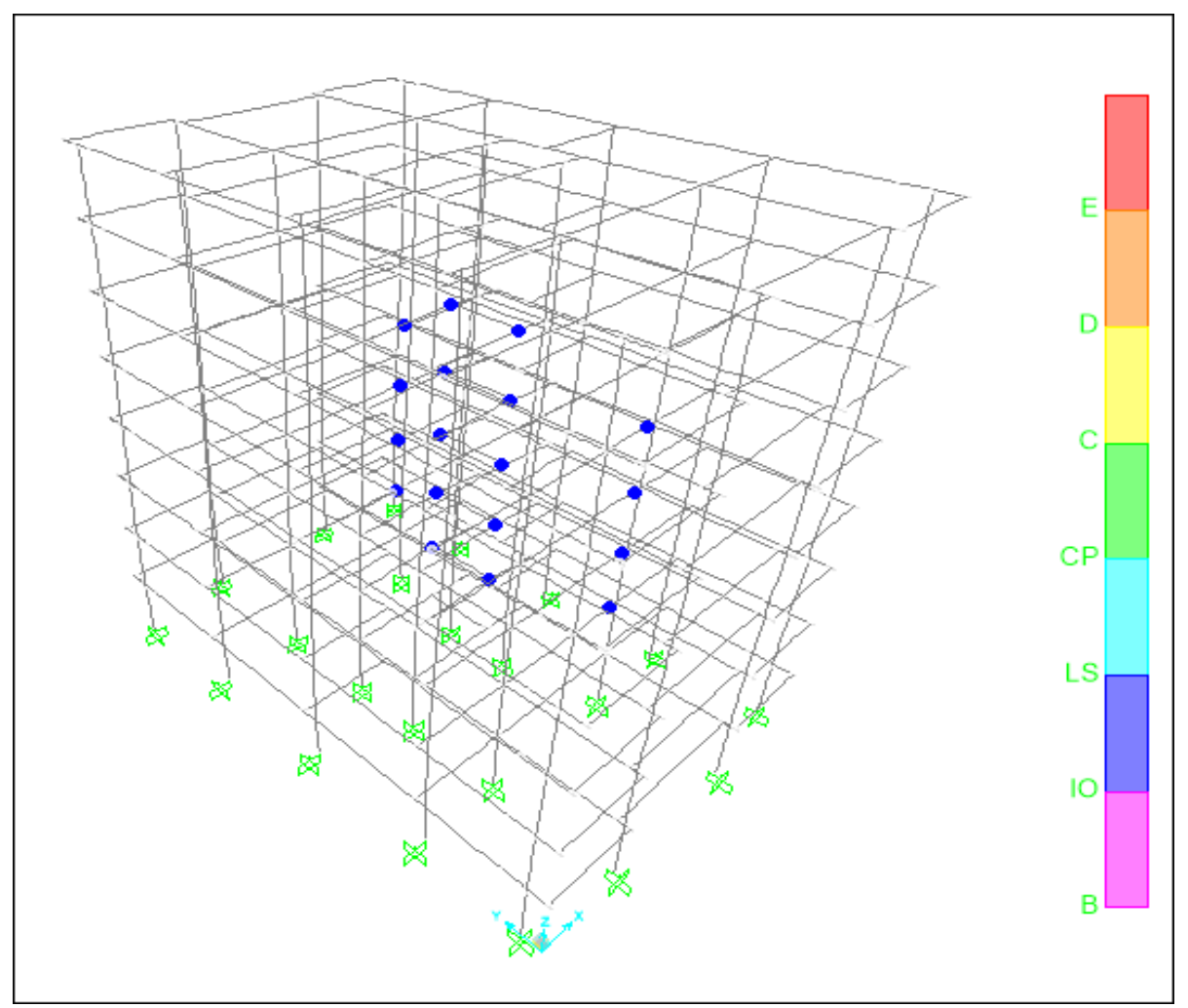

Şekil 10a. X doğrultusunda yapılan itme analizi sonucu taşıyıcı elemanlarda meydana gelen hasarlar

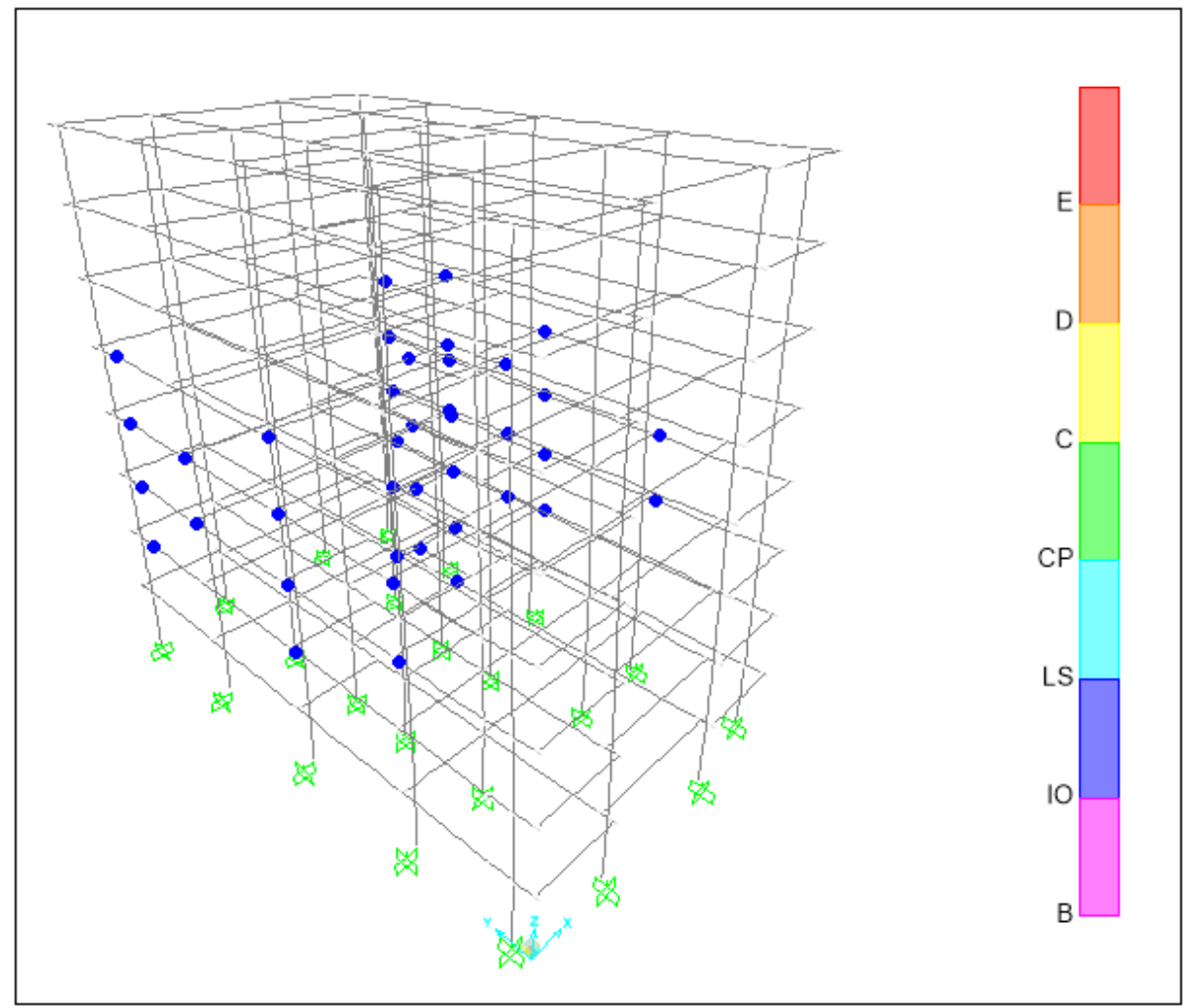

Şekil 10a. $\mathrm{X}$ doğrultusunda yapılan itme analizi sonucu taşıyıcı elemanlarda meydana gelen hasarlar

Şekil 10 incelendiğinde tüm katlarda tüm düşey taşıyıcı elemanlarda herhangi bir hasar meydana gelmediği görülmektedir. Kirişlerdeki hasar incelendiğinde ise bazı kirişlerin belirgin hasar bölgesinde kaldığı görülmektedir. Mafsallaşma renginin mavi olması ilgili elemandaki hasarın sınırlı hasar sınırını aştı̆̆ ve belirgin hasar bölgesinde kaldığını göstermektedir. Binanın performans seviyesinin belirlenmesi için kat ve doğrultu bazında belirgin hasar bölgesine geçen kirişlerin oransal olarak 
belirlenmesi gerekmektedir. Şekil 11a'da X doğrultusu için Şekil 11b'de ise Y doğrultusu için katlara göre kirişlerin yüzdelik olarak ne kadarının hangi hasar bölgesinde kaldığını görülmektedir.

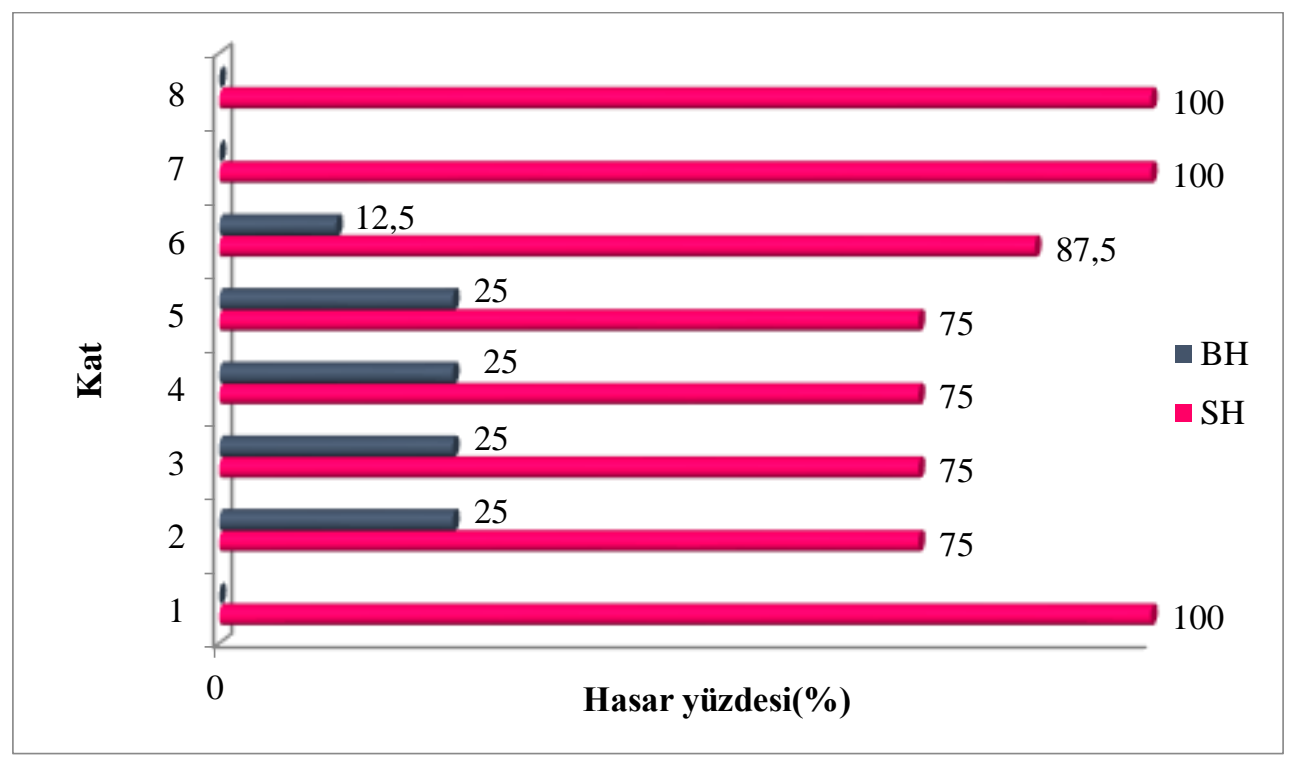

Şekil 11a. $X$ doğrultusu için yüzdelik olarak kiriş hasar bölgeleri

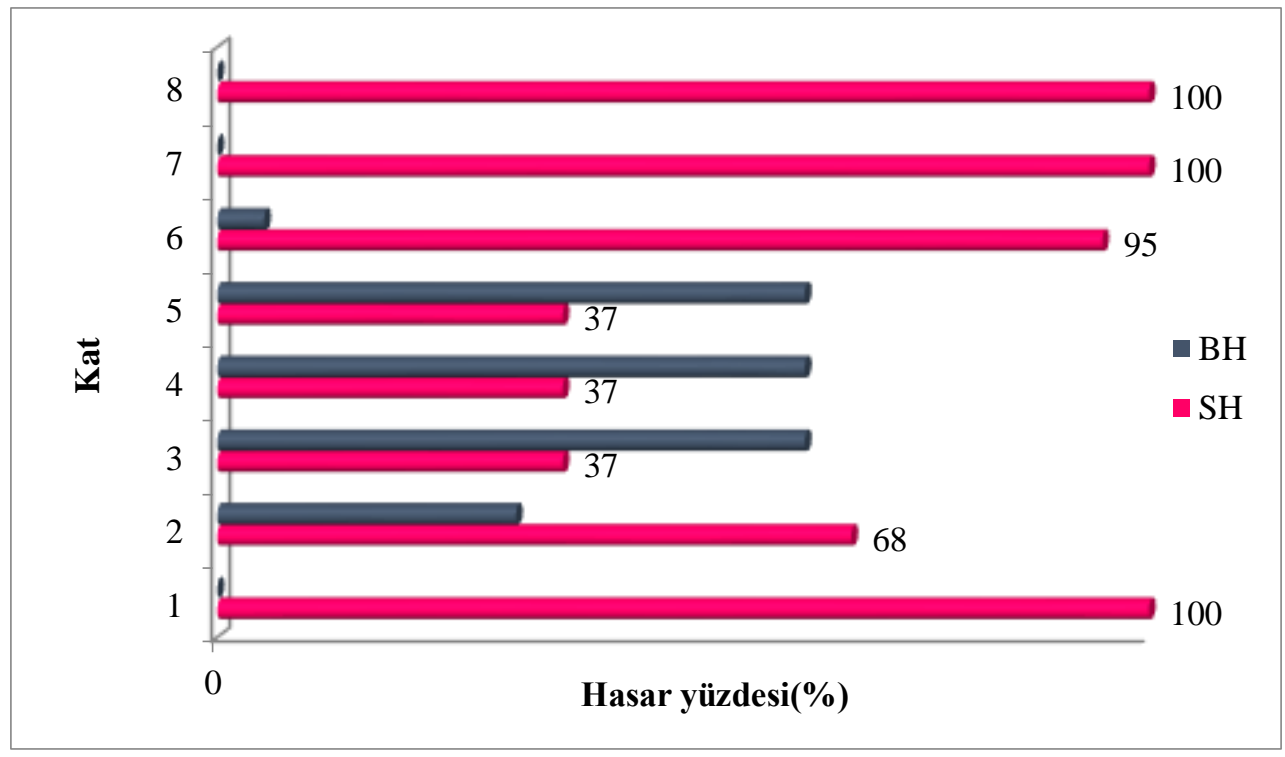

Şekil 11b. Y doğrultusu için yüzdelik olarak kiriş hasar bölgeleri

Düşey taşıyıcı elemanlarda hasar oluşmadığı için bina performans seviyesi kiriş hasarlarına bakılarak karar verilmiştir. TBDY 2018 [6]'e göre binanın herhangi bir katında, her iki deprem doğrultusu için yapılmış olan performans analizi sonucu, belirgin hasar bölgesi'ne geçen kiriş sayısı ilgili doğrultudaki toplam kirişlerin \%20'sine eşit veya altında ise ilgili katın performans düzeyi Sınırlı'dır. 1., 6., 7. ve 8. katlarda her iki doğrultuda da belirgin hasar bölgesindeki kirişlerin yüzdesi 20'nin altında kalmaktadır. Dolayısı ile 1., 6., 7. ve 8. katlar Sinırlı Hasar Performans Düzeyinde'dir. 2., 3., 4., 5. katlar da ise her iki doğrultuda da belirgin hasar bölgesi'ne geçen kiriş sayısı ilgili doğrultudaki toplam kirişlerin \%20'sinden fazladır ama ileri hasar bölgesine geçen kiriş yoktur. Dolayısıyla 2., 3., 4., 5. katlar Kontrollü Hasar Performans Düzeyi'ndedir.

Tüm katlar içindeki en elverişsiz performans düzeyi binanın performans düzeyi olarak belirlenir. Bu durumda bina Kontrollü Hasar Performans Düzeyi'ndedir. TBDY 2018'e göre binanın hedef performans seviyesi DD-2 deprem düzeyi için Kontrollü Hasar Performans Düzeyi olmas1 gerekmektedir. Bina yönetmelikte verilen hedef performans seviyesini sağlamaktadır. 


\section{Tartışma ve Sonuç}

Bu çalışmada, TBDY (2018) [6]'e göre tasarlanan ve yapımına devam edilen betonarme bir binanın incelenmek üzere proje verileri elde edilmiştir. Binanın doğrusal elastik olmayan değerlendirme yöntemlerinde tek modlu itme analizi ile performans analizi yapılmıştır. Bina daha yapım aşamasında olduğundan yeni yapılacak bir bina gibi değerlendirilip performans analizi bu kapsamda yapılmıştır. Yapılan incelemeler sonucu aşağıdaki sonuçlar elde edilmiştir.

- Yeni yapılacak binaların deprem performansının belirlenmesinde, mevcut binaların performansının belirlenmesine göre en belirgin farklardan biri etkin kesit çarpanları ile ilgilidir. Mevcut binalarda çubuk eleman olarak modellenen kiriş, kolon ve betonarme perdeler için eksenel etkin kesit çarpanları sırasıyla $0.35,0.7$ ve $0.5 \mathrm{iken}$, yeni yapılan binalarda elemanların her birinin etkin kesit çarpanları için moment eğrilik analizinin yapılması gerekmektedir. $\mathrm{Bu}$ çalışmada kirişlerin etkin kesit çarpanları 0.0848-0.1921 arasında, kolonların etkin kesit çarpanları 0.0455-0.1916 arasında, betonarme perdelerin etkin kesit çarpanları ise 0.04520.2653 arasında çıkmıştır.

- Yapilan tek modlu itme analizi sonucu kolon ve betonarme perdelerde herhangi bir hasar meydana gelmediği, kirişlerin ise bazılarının belirgin hasar bölgesinde kaldığ

- Düşey taşıyıcı elemanlarda hasar oluşmadığı için bina performans seviyesi kiriş hasarlarına bakılarak karar verilmiştir. Yapılan değerlendirme sonucu 1., 6., 7. ve 8. katların Sınırlı Hasar Performans Düzeyinde, 2., 3., 4. Ve 5. katların ise Kontrollü Hasar Performans Düzeyi'nde olduğu belirlenmiştir.

- Tüm katlar içindeki en elverişsiz performans düzeyi, binanın performans düzeyi olarak belirlenmiştir. Dolayısıyla binanın Kontrollü Hasar Performans Düzeyi’nde olduğu tespit edilmiştir.

- TBDY 2018'e göre binanın DD-2 deprem düzeyi için Kontrollü Hasar Performans Düzeyi’ni sağlaması gerekmektedir. Bina yönetmelikte verilen hedef performans seviyesini sağladığ1 belirlenmiştir.

- Binanın betonarme perde elemanlarının kalıp planında uygun yerlerde simetrik ve düzenli bir şekilde yerleştirilmesi düşey taşıııı elemanların hasar görmemesinde ve binanın hedef performans seviyesini sağlamasında etkili olduğu söylenebilir.

- TBDY (2018) [6]'in yeni bir yönetmelik olması sebebiyle gerek özel gerekse kamuda çalışan mühendislere bazı kavramların örneklerle açıklanması ihtiyacını doğurmaktadır. Bu çalışma ile yeni deprem yönetmeliğinin kavranabilmesi noktasında karşılaşılabilecek problemlere 1 ş1k tutması amaçlanmıştır. Yönetmeliğin farklı bölümleri için de bu tür çalışmaların yapılması nitelikli mühendis sayısını artıracağı düşünülmektedir.

\section{Yazarların Katkısı}

Çalışmada tüm yazarlar eşit oranda katkı sunmuştur.

\section{Çıkar Çatışması Beyanı}

Yazarlar arasında herhangi bir çıkar çatışması bulunmamaktadır.

\section{Araştırma ve Yayın Etiği Beyanı}

Yapılan çalışmada araştırma ve yayın etiğine uyulmuştur.

\section{Kaynaklar}

[1] Yalın M. 2020. Mevcut Bir Okul Binasının Deprem Performansının 2007 ve 2018 Deprem Yönetmeliklerine göre Değerlendirilmesi. Yüksek Lisans Tezi, Burdur Mehmet Akif Ersoy Üniversitesi, Fen Bilimleri Enstitüsü, Burdur, 1-175. 
[2] ATC 40. 1996. Seismic Evaluation and Retrofit of Concrete Buildings, Applied Technology Council, California, ABD.

[3] FEMA 356. 2000. Prestandard and Commentary for the Seismic Rehabilitation of Buildings. Federal Emergency Management Agency, Washington DC.

[4] Turkay A., Guler K. 2017. Bir Okul Binasının Tasarımı ve Deprem Performansının Değerlendirilmesi. International Journal of Innovative Engineering Applications, 1 (2): 27-37.

[5] DBYBHY 2007. Deprem Bölgelerinde Yapılacak Binalar Hakkındaki Yönetmelik. Bayındırlık ve İskân Bakanlığı, Ankara.

[6] TBDY 2018. Türkiye Bina Deprem Yönetmeliği. Afet ve Acil Durum Yönetimi Başkanlığ1, Ankara.

[7] Dilmaç H., Ulutaş H., Tekeli H., Demir F. 2018. An Evaluation on Seismic Performance of Existing Reinforced Concrete Buildings in Turkey. Mehmet Akif Ersoy Üniversitesi Fen Bilimleri Enstitüsü Dergisi, 9(Ek Sayı 1): 224-237.

[8] Gündoğay A., Tekeli H., Ulutaş H. 2019. Mevcut Atölye Binalarının Deprem Güvenliğinin İncelenmesi. DÜMF Mühendislik Dergisi, 10 (2): 755-768.

[9] Dilmaç H. 2020. Preliminary Assessment Approach to Predict Seismic Vulnerability of Existing Low and Mid-Rise RC Buildings. Bulletin of Earthquake Engineering, 75 (2): 211-227.

[10] Özdemir M., Iş̧1k E., Ülker E. 2016. Farklı Kat Adetlerine Sahip Betonarme Binaların Performans Değerlendirilmesi. BEÜ Fen Bilimleri Dergisi, 5 (2): 183-190.

[11] Ulutaş H., Dilmaç H., Tekeli H., Demir F. 2019. Mevcut Okul Türü Binaların Deprem Güvenliğinin Pratik Bir Şeklide Belirlenmesi için Bir Yaklaşım: ATI. Süleyman Demirel Üniversitesi Fen Bilimleri Enstitüsü Dergisi, 23 (2): 329-337.

[12] Dilmaç H., Ulutaş H., Tekeli H., Demir F. 2018. The investigation of seismic performance of existing RC buildings with and without infill walls. Computers and Concrete, 22 (5): 439-447. DOI: $10.12989 / \mathrm{cac} .2018 .22 .5 .000$

[13] Işık E., Öztürk G. 2017. Betonarme Binalarda Kat Yüksekliğinin Yapı Performansına Etkisi. Karaelmas Fen ve Mühendislik Dergisi, 7 (1) : 299-305.

[14] Kap T., Özgan E., Uzunoğlu M. M. 2019. Betonarme Bir Okul Binasının 2018 Deprem Yönetmeliğine göre İncelenmesi. Düzce Üniversitesi Bilim ve Teknoloji Dergisi, 7 (1): 11401150.

[15] Kürkçü F. 2020. 20 Katlı Betonarme Bir Yapının Türkiye Bina Deprem Yönetmeliği’ne göre Tasarımı ve Deprem Performansının Belirlenmesi. Yüksek Lisans Tezi, İstanbul Teknik Üniversitesi, Fen Bilimleri Enstitüsü, İstanbul, 1-237.

[16] Akçora A. A. 2020. Betonarme Yüksek Binaların 2018 Y1lı Türkiye Bina Deprem Yönetmeliğine göre İncelenmesi: 30 Katlı Bina Örneği. Yüksek Lisans Tezi, Yıldız Teknik Üniversitesi, Fen Bilimleri Enstitüsü, İstanbul. 1-161.

[17] Çapa Y. U. 2020. Kat Adetleri Farklı Betonarme Binaların Deprem Performanslarının İncelenmesi. Yüksek Lisans Tezi, Fatih Sultan Mehmet Vakıf Üniversitesi, Lisansüstü Eğitim Enstitüsü, İstanbul, 1-113.

[18] SAP2000. Integrated Finite Element Analysis and Design of Structures, Computers and Structures Inc., Berkeley, California, USA. 